\title{
Land Cover and Land Use Indicators
}

REVIEW OF AVAILABLE DATA 


\section{OECD GREEN GROWTH PAPERS}

The OECD Green Growth Strategy, launched in May 2011, provides concrete recommendations and measurement tools to support countries' efforts to achieve economic growth and development, while at the same time ensuring that natural assets continue to provide the ecosystem services on which our well-being relies. The strategy proposes a flexible policy framework that can be tailored to different country circumstances and stages of development.

This paper has been authorised for publication by Mr. Simon Upton, Director, Environment Directorate. OECD Green Growth Papers should not be reported as representing the official views of the OECD or of its member countries. The opinions expressed and arguments employed are those of the author(s). The statistical data for Israel are supplied by and under the responsibility of the relevant Israeli authorities. The use of such data by the OECD is without prejudice to the status of the Golan Heights, East Jerusalem and Israeli settlements in the West Bank under the terms of international law. This document and any map included herein are without prejudice to the status of or sovereignty over any territory, to the delimitation of international frontiers and boundaries and to the name of any territory, city or area.

OECD Green Growth Papers aim to describe preliminary results or research in progress by the author(s) and are published to stimulate discussion on specific topics and obtain feedback from interested audiences.

They complement the OECD Green Growth Studies series, which aims to provide in-depth reviews of the green growth issues faced by different sectors.

Comments on Green Growth Papers are welcomed, and may be sent to: OECD Green Growth Unit, 2, rue André Pascal, 75775 PARIS CEDEX 16, France or by email to greengrowth@oecd.org.

OECD Green Growth Papers are published on: www.oecd.org/greengrowth

Please cite this paper as:

Diogo, V. and Koomen, E. (2016), "Land Cover and Land Use Indicators: Review of Available Data", OECD Green Growth Papers, No. 2016/03, OECD Publishing, Paris.

\section{(C) OECD (2016)}

You can copy, download or print OECD content for your own use, and you can include excerpts from OECD publications, databases and multimedia products in your own documents, presentations, blogs, websites and teaching materials, provided that suitable acknowledgment of OECD as source and copyright owner is given.

All requests for commercial use and translation rights should be submitted to rights@oecd.org. 


\begin{abstract}
This paper identifies opportunities to refine OECD's indicators of land cover and land use and their regular production for all OECD and G20 countries. A comprehensive review is conducted of the available datasets at the global, regional and national levels, including data derived from remote sensing as well as those complemented with administrative and survey data. The datasets are assessed in terms of their geographic coverage, periodicity, spatial resolution, data reliability and comparability. The paper discusses the potential use of such datasets for the production of indicators that are harmonised across countries and over time. It is found that data on land cover are widely available and that many OECD countries have good-quality national land cover datasets, in some cases consistently over time. However, considerable differences have been found among the land cover products reviewed in terms of their geographic coverage, spatial, temporal and thematic resolution. For eight countries, no country- or region-specific data could be found (including Israel, Korea, Colombia, Costa Rica, India, Indonesia, the Russian Federation and Saudi Arabia). On the other hand, data on land use seem to be much scarcer, available only for Australia, European countries, Japan and the United States. The paper concludes with a discussion of selection guidelines for, and examples of, potentially suitable datasets in terms of their geographic coverage and the temporal, spatial and thematic resolution.
\end{abstract}

JEL classification: Q56, Q57, R11, R14, R52

Keywords: land cover, land use, remote sensing, satellite data

\title{
RÉSUMÉ
}

Ce rapport identifie les possibilités d'affiner les indicateurs de l'OCDE sur l'occupation et l'utilisation des terres, ainsi que leur production régulière pour tous les pays de l'OCDE et ceux du G20. Il propose un examen complet des ensembles de données disponibles au niveau mondial, régional et national, incluant les données de télédétection et les informations complétées par des données administratives et tirées d'enquêtes. Les sources de données sont évaluées par rapport à leur couverture géographique, périodicité, fiabilité et comparabilité de l'information. Le rapport étudie l'utilisation potentielle de ces ensembles de données pour produire des indicateurs harmonisés entre pays et dans le temps. On constate que les données sur la couverture du sol sont largement disponibles et que de nombreux pays de l'OCDE ont des données nationales de bonne qualité, parfois même consistantes dans le temps. Néanmoins, des différences importantes persistent parmi les produits de couverture du sol examinés, en particulier la couverture géographique, la résolution spatiale et thématique et la précision des données. Pour huit pays (Israël, la Corée, la Colombie, le Costa Rica, l’Inde, l’Indonésie, la Fédération de Russie et l'Arabie saoudite), aucune donnée nationale ou régionale n'a pu être trouvée. Les données sur l'utilisation des terres semblent en revanche bien plus rares et ne sont disponible que pour l'Australie, les pays européens, le Japon et les États-Unis. Ce rapport conclut avec une discussion sur les méthodes de sélection, ainsi que des exemples de sources de données potentiellement adéquates en termes de couverture géographique, de résolution temporelle, spatiale et thématique.

Classification JEL : Q56, Q57, R11, R14, R52

Mots clés : occupation des terres, utilisation des terres, télédétection, données satellitaires 


\section{ACKNOWLEDGEMENTS}

This paper was prepared for the OECD by Vasco Diogo and Eric Koomen of the Spatial Information Laboratory, Faculty of Economics and Business Administration, Vrije Universiteit Amsterdam, the Netherlands. Ivan Haščič of the OECD Secretariat provided overall guidance and final text editing. OECD colleagues including Miguel Cárdenas Rodríguez, Nathalie Girouard, Myriam Linster, Alexander Mackie, Mauro Migotto, Walid Oueslati and Valentine Rinner also provided helpful inputs on an earlier draft of the paper. Jennifer Humbert and Jacqueline Maher provided editorial assistance.

The paper was reviewed by the OECD Environmental Policy Committee and its Working Party on Environmental Information, and benefited from the comments received. 


\section{FOREWORD}

Indicators of land cover and land use are included in the OECD core set of Environmental indicators, in the set of OECD Green Growth indicators, in the OECD Agri-environmental indicators and in the OECD’s Territorial indicators.

In 2014, the OECD Working Party on Environmental Information (WPEI) requested the Secretariat to develop a detailed proposal on the way to define and calculate indicators of changes in land use and cover, considering the pros and cons of using different data sources (e.g., remotely sensed versus administrative and survey data).

This paper takes a first step towards developing policy-relevant indicators of changes in land use and cover that are standardised across countries and over time. It presents a comprehensive review of availability of data on land cover and land use across all OECD and G20 countries. Future work will make specific proposals for the indicators to be used in OECD work, and review the policy messages that can be derived from such indicators.

It should be noted that this paper does not take into account the data on land use and cover compiled by the OECD from other international sources including FAO (land use statistics, forest resource assessment) and Eurostat, nor the land use and cover classification used in the OECD questionnaire on the state of the environment (section on land). These data are aggregated by countries according to criteria specified in the questionnaire and do not provide the granularity that would be required to both generate meaningful indicators and support policy analysis and empirical work at the OECD. This paper explores the availability of detailed data from Earth observation systems and from surveys and administrative sources that are available publicly and updated at regular intervals. The focus is on datasets that can be easily accessed so as to calculate internationally harmonised indicators without adding to the response burden of countries. 
TABLE OF CONTENTS

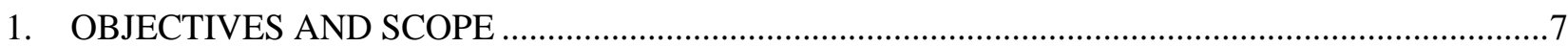

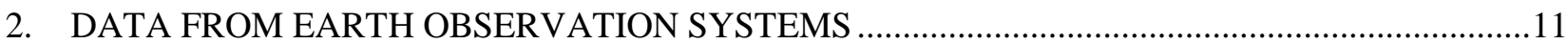

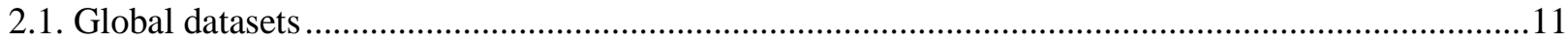

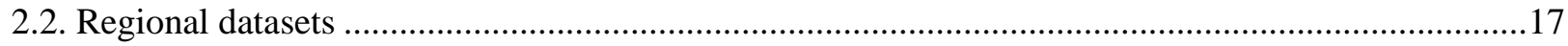

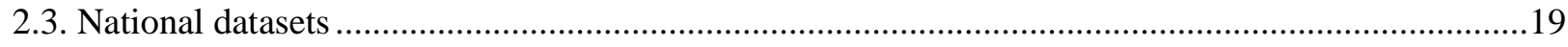

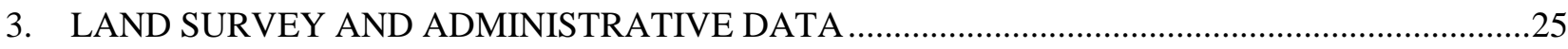

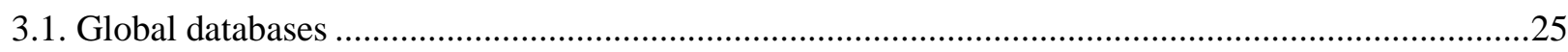

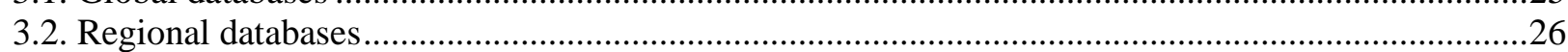

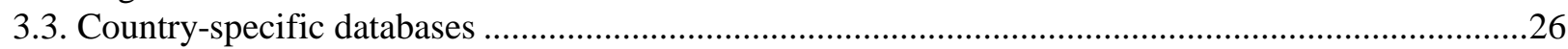

4. CONCLUSIONS ON THE USAGE OF THE AVAILABLE DATA ……..........................................29

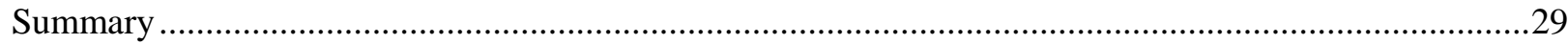

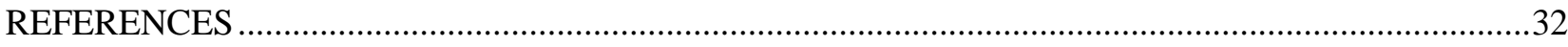

ANNEX A: SYSTEMS OF LAND COVER AND LAND USE CLASSIFICATION ................................35

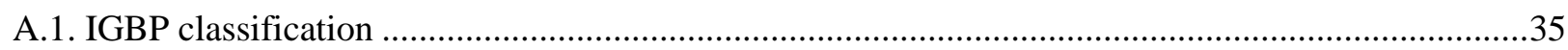

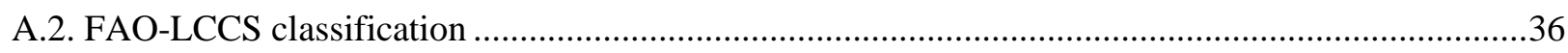

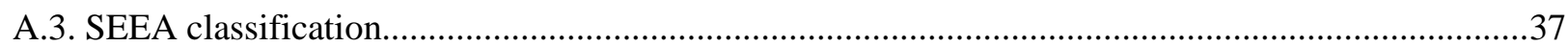

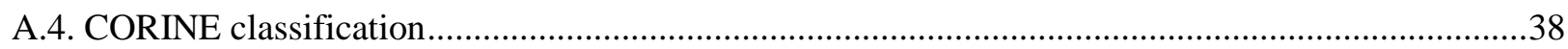

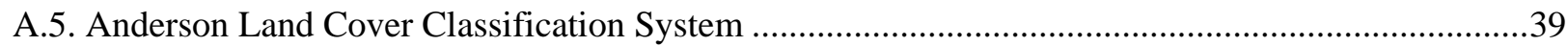

ANNEX B: SELECTED SOURCES OF ENVIRONMENTAL, GEOPHYSICAL AND

SOCIO-ECONOMIC GEO-REFERENCED DATA ……....................................................................... 


\section{OBJECTIVES AND SCOPE}

The availability of relevant land cover and land use data is reviewed across all OECD and G20 countries. ${ }^{1}$ Land cover and land use data are commonly made available as categorical maps derived through semi-automated methods which use remote sensing images as the main input. The scope of the review is limited to large-area officially published land cover or land use products released before the end of $2015 .^{2}$

Although the terms 'land cover' and 'land use' are sometimes used interchangeably, it is widely acknowledged that they refer to different concepts (Comber, 2008). 'Land cover' refers to the physical surface characteristics of land, such as the type of vegetation or the presence of artificial structures. 'Land use' describes the economic and social functions of land to meet demands for food, fibre, shelter, and natural resources. Although the two concepts may be largely linked, the linkages between them are complex. A land cover like grassland may support many land uses, including livestock production and recreation, while a single use, e.g. mixed farming, may take in a number of different cover types including grassland, cropped and fallow areas (Haines-Young, 2009). However, while the distinction between cover and use is accepted, they are often conflated in classification schemes (Di Gregorio and Jansen, 2000). In this paper, we will differentiate between land cover and land use whenever the distinction is relevant.

While preference was given to sources of land cover and land use data based on Earth observation systems (Chapter 2), examples of land survey and administrative data are also given as alternative and complementary data sources (Chapter 3). While reviewing the identified data sources, we distinguish between three levels of geographical coverage: global level, regional level and country level.

For data derived from Earth observation systems, the following characteristics are discussed:

- data capture - the methods used for measurement, data collection and processing;

- reliability - the quality, accuracy and completeness of the dataset;

- geographical coverage - the area covered by the dataset;

- format - whether the dataset is available in raster or vector format;

- spatial resolution - the size of the smallest features captured. In raster format, resolution is expressed as the approximate size of the raster grid. In vector format, it is a function of the cartographic scale of the source map among other factors. The spatial resolution of land cover products is typically determined by the imaging resolution of the sensor(s) used to make the source observations;

- temporal resolution - the periodicity with which datasets are produced, and the years for which datasets are available;

- thematic resolution - the types of land cover or socio-economic use that are distinguished in the dataset, including the classification used;

- data source - the institution responsible for issuing the dataset and how the data can be accessed.

These characteristics are discussed in detail below. For each dataset, we first describe the data collection and classification method, followed by the results of accuracy assessment (when available), in order to infer on the reliability of the data products. ${ }^{3}$ The findings of our review are summarised below in Table 1. Conclusions about the potential use of the reviewed data are provided in Section 4.

\footnotetext{
Comprising a total of 46 countries: 35 OECD members, 3 OECD accession candidates and 8 remaining G20 countries.
}

There is a complementary type of land cover research that focusses on one class of land cover and aims to describe phenomena that relate only to that specific class in more detail. An archetypal global example would be the Forest Cover Change Map (Hansen et al., 2013). These binary datasets are not included in the scope of this review.

3 It is important to note that is it challenging to define and measure 'accuracy' in these kinds of products and that accuracy is not the same thing as fitness-for-use. Furthermore, accuracy can be assessed in different ways so accuracy figures are not necessarily comparable between datasets. 
Table 1. Summary of the datasets reviewed

\begin{tabular}{|c|c|c|c|c|c|c|c|c|}
\hline Product & $\begin{array}{l}\text { Measurement } \\
\text { method }\end{array}$ & $\begin{array}{l}\text { Reported } \\
\text { accuracy }\end{array}$ & $\begin{array}{l}\text { Geographical } \\
\text { coverage }\end{array}$ & Spatial resolution & \begin{tabular}{|l|} 
Time periods \\
available
\end{tabular} & Thematic resolution & Format & Data Source \\
\hline $\begin{array}{l}\text { Global Land Cover } \\
\text { Characterization }\end{array}$ & $\begin{array}{l}\text { Based on AVHHR } \\
\text { satellite imagery }\end{array}$ & $\begin{array}{l}81 \%-90 \% \\
\text { (training data) }\end{array}$ & $\begin{array}{l}\text { Global } \\
\text { (aggregated dataset) }\end{array}$ & $1^{\circ}, 8 \mathrm{~km}$ and $1 \mathrm{~km}$ & $\begin{array}{l}\text { Only available for } \\
1984\end{array}$ & Land cover (IGBP) & Raster & "http://glcf.umd.edu/data/landcover/data.sht \\
\hline $\begin{array}{l}\text { Global Land Cover } \\
\text { Classification (GLCC) }\end{array}$ & \begin{tabular}{|l|}
$\begin{array}{l}\text { Based on AVHHRR } \\
\text { satellite imagery }\end{array}$ \\
\end{tabular} & $65 \%-82 \%$ & $\begin{array}{l}\text { Global } \\
\text { (aggregated dataset) }\end{array}$ & $1 \mathrm{~km}$ & $\begin{array}{l}\text { Only available for } \\
\text { 1992-1993 }\end{array}$ & Land cover (IGBP) & Raster & https://ta.cr.usgs.gov/GLCC \\
\hline GLC 2000 & $\begin{array}{l}\text { Based on SPOT } 4 \\
\text { satellite imagery }\end{array}$ & $66 \%-69 \%$ & $\begin{array}{l}\text { Global and regional } \\
\text { (aggregated dataset) }\end{array}$ & $1 \mathrm{~km}$ & $\begin{array}{l}\text { Only available for } \\
2000 \\
\end{array}$ & $\begin{array}{l}\text { Land cover } \\
\text { (FAO-LCCS) }\end{array}$ & Raster & $\begin{array}{l}\text { http://bioval.jpc.ec.europa.eu/products/glc2000/produ } \\
\text { cts.php }\end{array}$ \\
\hline MODIS Land Cover & $\begin{array}{l}\text { Based on MODIS } \\
\text { satellite imagery }\end{array}$ & 2005: $75 \%$ & $\begin{array}{l}\text { Global } \\
\text { (mosaics and } \\
\text { aggregated dataset) }\end{array}$ & \begin{tabular}{|l|}
$500 m$ (mosaics) \\
or $5^{\prime}$ and $0.5^{\circ}$ \\
(aggregated global \\
dataset)
\end{tabular} & $\begin{array}{l}\text { Every year between } \\
2001-2012\end{array}$ & Land cover (IGBP) & Raster & $\begin{array}{l}\text { ftp://glcf.umd.edu/glcf/Global_LNDCVR/UMD_TILES } \\
\text { /Nersion_5.1/ }\end{array}$ \\
\hline SYNMAP & $\begin{array}{l}\text { Merging of GLCC, } \\
\text { GLC } 2000 \text { and } \\
\text { MODIS } 2001\end{array}$ & - & $\begin{array}{l}\text { Global } \\
\text { (aggregated dataset) }\end{array}$ & $1 \mathrm{~km}$ & $\begin{array}{l}\text { Only available for } \\
\text { (circa) } 2000\end{array}$ & Land cover (SIMPLE) & Raster & $\begin{array}{l}\text { http://webmap.ornl.gov/wcsdown/dataset.jsp?ds_id= } \\
10024\end{array}$ \\
\hline GlobCover & \begin{tabular}{|l|} 
Based on MERIS \\
satellite imagery
\end{tabular} & $\begin{array}{l}\text { 2005: } 73 \% \\
\text { 2009: } 68 \% \\
\end{array}$ & $\begin{array}{l}\text { Global } \\
\text { (aggregated dataset) }\end{array}$ & $300 \mathrm{~m}$ & 2005 and 2009 & $\begin{array}{l}\text { Land cover } \\
\text { (FAO-LCCS) }\end{array}$ & Raster & http://due.esrin.esa.int/globcover/ \\
\hline CCI-LC & \begin{tabular}{|l|} 
Based on MERIS and \\
SPOT-Vegetation \\
satellite imagery \\
\end{tabular} & 2008-2012: 74\% & $\begin{array}{l}\text { Global } \\
\text { (aggregated dataset) }\end{array}$ & $300 \mathrm{~m}$ & \begin{tabular}{|l|}
$1998-2002$, \\
$2003-2007$ and 2008- \\
2012 \\
\end{tabular} & Land cover (FAO-LCCS) & Raster & http://maps.elie.ucl.ac.be/CCI/viewer/download.php \\
\hline $\begin{array}{l}\text { Global Land Survey (and } \\
\text { derived products Landsat } \\
\text { Tree Cover Continuous } \\
\text { Fields and Landsat Forest } \\
\text { Cover Change) }\end{array}$ & $\begin{array}{l}\text { Satellite imagery } \\
\text { collected from } \\
\text { Landsat sensors }\end{array}$ & - & \begin{tabular}{|l} 
Global \\
(mosaics)
\end{tabular} & $30 \mathrm{~m}$ & \begin{tabular}{|l|}
1975,1990, \\
2000, 2005 \\
(LTCCF and LFCC \\
only available for \\
2000 and 2005) \\
\end{tabular} & $\begin{array}{l}\text { HR satellite imagery, } \\
\text { Tree cover, Forest cover } \\
\text { change }\end{array}$ & Raster & $\begin{array}{l}\text { GLS: } \\
\text { http://glcf.umd.edu/data/gls/ } \\
\text { TC: } \\
\text { http://glcf.umd.edu/data/landsatTreecover/ } \\
\text { FCC: http://glcf.umd.edu/data/landsatFCC/ }\end{array}$ \\
\hline FROM-GLC 30m & $\begin{array}{l}\text { Based on Landsat } \\
\text { TM/ETM+ satellite } \\
\text { imagery }\end{array}$ & $64 \%-66 \%$ & \begin{tabular}{|l} 
Global \\
(mosaics)
\end{tabular} & $30 \mathrm{~m}$ & $\begin{array}{l}\text { Only available for } \\
2006\end{array}$ & $\begin{array}{l}\text { Land cover (compatible } \\
\text { with IGBP and FAO- } \\
\text { LCCS) }\end{array}$ & Raster & http://data.ess.tsinghua.edu.cn/ \\
\hline GlobLand30 & \begin{tabular}{|l|} 
Based on Landsat \\
TM/ETM+ and \\
HJ-1 satellite imagery
\end{tabular} & 2010: 79\% & \begin{tabular}{|l} 
Global \\
(mosaics)
\end{tabular} & $30 \mathrm{~m}$ & 2000 and 2010 & $\begin{array}{l}\text { Land cover } \\
\text { (GlobLand30 legend) }\end{array}$ & Raster & $\begin{array}{l}\text { http://www.globallandcover.com/GLC30Download/in } \\
\text { dex.aspx }\end{array}$ \\
\hline GLC-Share & \begin{tabular}{|l|} 
Harmonisation of \\
national, regional and \\
global databases
\end{tabular} & $80 \%$ & $\begin{array}{l}\text { Global } \\
\text { (aggregated dataset) }\end{array}$ & $\begin{array}{l}30 \text { arc-second } \\
(\sim 1 \mathrm{~km})\end{array}$ & & \begin{tabular}{|l|} 
Percentage of each land \\
cover per grid cell and \\
dominant land cover \\
(SEEA)
\end{tabular} & Raster & http://www.glcn.org/databases/lc_glcshare_en.jsp \\
\hline CORINE Land Cover & \begin{tabular}{|l|} 
Based on SPOT, \\
Landsat TM and MSS \\
satellite imagery, \\
complemented with \\
ancillary data \\
available at the \\
country level
\end{tabular} & 2000: 87\% & \begin{tabular}{|l|} 
EU-28, Albania, Bosnia \\
and Herzegovina, \\
Former Yugoslav \\
Republic of Macedonia, \\
Iceland, Kosovo \\
Liechtenstein, \\
Montenegro, Norway, \\
Serbia, Switzerland, and \\
Turkey \\
\end{tabular} & $\begin{array}{l}1: 100,000 \text { (vector) } \\
\text { or } \\
100 \mathrm{~m} \text { (raster) }\end{array}$ & $\begin{array}{l}\text { 1990, 2000, } 2006 \\
\text { (2012 foreseen) }\end{array}$ & $\begin{array}{l}\text { Land cover and land use } \\
\text { (CORINE, based on } \\
\text { FAO-LCCS) }\end{array}$ & \begin{tabular}{|l|} 
Vector \\
and raster
\end{tabular} & $\begin{array}{l}\text { http://glossary.eea.europa.eul/terminology/sitesearc } \\
\text { h?term=corine+land+cover }\end{array}$ \\
\hline
\end{tabular}




\begin{tabular}{|c|c|c|c|c|c|c|c|c|}
\hline Product & $\begin{array}{l}\text { Measurement } \\
\text { method }\end{array}$ & \begin{tabular}{|l|} 
Reported \\
accuracy
\end{tabular} & $\begin{array}{l}\text { Geographical } \\
\text { coverage }\end{array}$ & \begin{tabular}{|l|} 
Spatial resolution \\
\end{tabular} & $\begin{array}{l}\text { Time periods } \\
\text { available }\end{array}$ & Thematic resolution & Format & Data Source \\
\hline North American LCMS & $\begin{array}{l}\text { Based on MODIS } \\
\text { satellite imagery }\end{array}$ & $\begin{array}{l}\text { Canada 2005: } \\
59 \%-69 \%\end{array}$ & $\begin{array}{l}\text { Canada, Mexico and the } \\
\text { United States }\end{array}$ & $250 \mathrm{~m}$ & 2005 and 2010 & $\begin{array}{l}\text { Land cover } \\
\text { (FAO-LCCS) }\end{array}$ & Raster & $\begin{array}{l}\text { http://www.cec.org/Page.asp?PagelD=122\&Contentl } \\
D=2336\end{array}$ \\
\hline PNECO & $\begin{array}{l}\text { Based on MODIS } \\
\text { TERRA and } \\
\text { LANDSAT TM } \\
\text { satellite imagery }\end{array}$ & Not reported & Argentina & $1: 500.000$ & 2006-2007 & $\begin{array}{l}\text { Land cover } \\
\text { (FAO-LCCS) }\end{array}$ & Vector & $\begin{array}{l}\text { Currently not available online. See report here (in } \\
\text { Spanish): http://inta.gob.ar/documentos/cobertura- } \\
\text { del-suelo-de-la-republica-argentina.-ano-2006-2007- } \\
\text { Iccs- } \\
\text { fao/at_multi_download/file/INFORME\%20TECNICO } \\
\% 20 \text { Iccs.pdf }\end{array}$ \\
\hline $\begin{array}{l}\text { National Dynamic Land } \\
\text { Cover }\end{array}$ & $\begin{array}{l}\text { Based on MODIS EVI } \\
\text { composites }\end{array}$ & Not reported & Australia & $250 \mathrm{~m}$ & $\begin{array}{l}2000-2008 \\
\text { Time series with a } \\
\text { dataset for each year } \\
\text { between } 2000 \text { and } \\
2010 \text { is expected to } \\
\text { be released }\end{array}$ & $\begin{array}{l}\text { Land cover } \\
\text { (FAO-LCCS) }\end{array}$ & Raster & $\begin{array}{l}\text { http://www.ga.gov.au/metadata- } \\
\text { gateway/metadata/record/gcat_71071 }\end{array}$ \\
\hline ALUMP & \begin{tabular}{|l|} 
Based on AVHRR \\
satellite imagery and \\
available land use \\
information, combined \\
with simulation of \\
agricultural crops \\
allocation
\end{tabular} & Not reported & Australia & 1:2,500,000 & \begin{tabular}{|l|}
$1992-1993$ \\
$1993-1994$ \\
$1996-1997$ \\
$1998-1999$ \\
$2000-2001$ \\
$2001-2002$ \\
$2005-2006$ \\
$2010-2011$ \\
\end{tabular} & $\begin{array}{l}\text { Land use } \\
\text { (ALUMC) }\end{array}$ & Vector & $\begin{array}{l}\text { http://www.agriculture.gov.au/abares/aclump/land- } \\
\text { use/data-download }\end{array}$ \\
\hline $\begin{array}{l}\text { Mapeamento Sitemático } \\
\text { do Uso da Terra }\end{array}$ & $\begin{array}{l}\text { Based on Landsat } \\
\text { ETM+ satellite } \\
\text { imagery }\end{array}$ & Not reported & $\begin{array}{l}\text { Brazil (mosaics, } \\
\text { incomplete) }\end{array}$ & $1: 250.000$ & $\begin{array}{l}2003 \text { and 2007, but } \\
\text { not for all mosaics }\end{array}$ & $\begin{array}{l}\text { Land use (inspired in } \\
\text { CORINE) }\end{array}$ & Vector & $\begin{array}{l}\text { http://www.ibge.gov.br/home/geociencias/default_pr } \\
\text { od.shtm\#REC_NAT }\end{array}$ \\
\hline Land Cover of Canada & $\begin{array}{l}\text { Based on AVHRR } \\
\text { satellite imagery }\end{array}$ & Not reported & $\begin{array}{l}\text { Canada (merged with } \\
\text { Vegetation Map of } \\
\text { Alaska dataset) }\end{array}$ & $1 \mathrm{~km}$ & 1998 & $\begin{array}{l}\text { Land cover (Alaska } \\
\text { Interim) }\end{array}$ & Raster & $\begin{array}{l}\text { http://agdc.usgs.gov/data/usgs/erosafo/akcan_Icc/ak } \\
\text { can_Icc.html }\end{array}$ \\
\hline $\begin{array}{l}\text { Canada Land Cover circa } \\
2000\end{array}$ & $\begin{array}{l}\text { Based on Landsat } 5 \\
\text { and Landsat } 7 \\
\text { satellite imagery }\end{array}$ & Not reported & Canada & \begin{tabular}{|l|} 
Not reported. \\
Based on data with \\
30m resolution \\
\end{tabular} & 2000 & Land Cover (EOSD) & \begin{tabular}{|l|} 
Vector \\
\end{tabular} & $\begin{array}{l}\text { http://www.geobase.ca/geobase/en/data/landcover/i } \\
\text { ndex.html }\end{array}$ \\
\hline $\begin{array}{l}\text { Catastro de los Recursos } \\
\text { Vegetacionales Nativos } \\
\text { de Chile }\end{array}$ & $\begin{array}{l}\text { Initially based on } \\
\text { panchromatic aerial } \\
\text { photography, } \\
\text { currently based on } \\
\text { SPOT } 5 \text { and } \\
\text { FORMOSAT-2 } \\
\text { satellite imagery }\end{array}$ & Not reported & $\begin{array}{l}\text { Chile (mosaics of } 15 \\
\text { regions) }\end{array}$ & 1:30.000 & $\begin{array}{l}\text { 1997, 2001, } 2007 \text { and } \\
2011\end{array}$ & $\begin{array}{l}\text { Land cover, land use, } \\
\text { property rights, forest } \\
\text { category, forest } \\
\text { establishment and } \\
\text { reforestation, biomass, } \\
\text { carbon, forest fires, } \\
\text { forestry resource } \\
\text { extraction }\end{array}$ & Vector & $\begin{array}{l}\text { Only } 2011 \text { available for download at: } \\
\text { http://ide.mma.gob.cl/ }\end{array}$ \\
\hline China Land Cover & $\begin{array}{l}\text { Based on Landsat } \\
\text { TM/ETM satellite } \\
\text { imagery }\end{array}$ & Not reported & China & $1: 10.000 .000$ & $\begin{array}{l}\text { 1990, 1995, 2000, } \\
2005,2008\end{array}$ & \begin{tabular}{|l|} 
Land cover and land use \\
(unknown classification)
\end{tabular} & Vector & $\begin{array}{l}\text { Data not available online.: } \\
\text { http://www.resdc.cn/data.aspx?DATAID=99 }\end{array}$ \\
\hline $\begin{array}{l}\text { National Land Numerical } \\
\text { Information }\end{array}$ & $\begin{array}{l}\text { Based on Landsat, } \\
\text { TERRA and ALOS } \\
\text { satellite imagery }\end{array}$ & Not reported & Japan (1km mosaics) & $100 \mathrm{~m}(1 / 10)$ mesh & $\begin{array}{l}1976,1987,1991, \\
1997,2006 \text { and } 2009\end{array}$ & $\begin{array}{l}\text { Land use } \\
\text { (classes differ per year) }\end{array}$ & Vector & $\begin{array}{l}\text { http://nlftp.mlit.go.jp/ksj-e/gml/datalist/KsjTmplt-L03- } \\
\text { a.html }\end{array}$ \\
\hline
\end{tabular}




\begin{tabular}{|c|c|c|c|c|c|c|c|c|}
\hline Product & $\begin{array}{l}\text { Measurement } \\
\text { method }\end{array}$ & $\begin{array}{l}\text { Reported } \\
\text { accuracy }\end{array}$ & $\begin{array}{l}\text { Geographical } \\
\text { coverage }\end{array}$ & Spatial resolution & $\begin{array}{l}\text { Time periods } \\
\text { available }\end{array}$ & Thematic resolution & Format & Data Source \\
\hline $\begin{array}{l}\text { Uso del Suelo y } \\
\text { Vegetacion }\end{array}$ & $\begin{array}{l}\text { 1976: aerial } \\
\text { photography } \\
\text { interpretation. } \\
\text { 1993, } 2000 \text { and 2007: } \\
\text { based on Landsat TM } \\
\text { satellite imagery }\end{array}$ & Not reported & Mexico & 1:250.000 & $\begin{array}{l}1976,1993,2000 \text { and } \\
2007\end{array}$ & $\begin{array}{l}\text { Land cover } \\
\text { (IFN2000) }\end{array}$ & Vector & $\begin{array}{l}\text { Year } 2011 \text { available in: http://geoweb.inegi.org.mx/- } \\
\text { descargausodesuelo250/ } \\
\text { Map visualisation and transition matrices for 1976, } \\
1993 \text { and } 2000 \text { are available in: http://mapas.- } \\
\text { inecc.gob.mx/\#!!/page_vegetacion }\end{array}$ \\
\hline LUCAS LUM & $\begin{array}{l}\text { Based on Landsat } \\
\text { and SPOT satellite } \\
\text { imagery }\end{array}$ & 2012: 95\% & New Zealand & $\begin{array}{l}\text { Not reported. } \\
\text { Based on data with } \\
\text { the following } \\
\text { resolution: } \\
1990-30 \mathrm{~m} \\
2008 \text { - 10m } 2012 \text { - } \\
10 \mathrm{~m}\end{array}$ & 1990,2008 and 2012 & $\begin{array}{l}\text { Land cover } \\
\text { (FAO-LCCS) }\end{array}$ & Vector & $\begin{array}{l}\text { https://koordinates.com/layer/4316-lucas-new- } \\
\text { zealand-land-use-map-1990-2008-2012-v011/ }\end{array}$ \\
\hline $\begin{array}{l}\text { National Land Use and } \\
\text { Cover }\end{array}$ & - & - & South Africa & - & - & $\begin{array}{l}\text { Land use } \\
\text { (CSDM) }\end{array}$ & - & $\begin{array}{l}\text { Data has not been released yet. More info in: } \\
\text { http://www.ngi.gov.za/index.php/technical- } \\
\text { information/publications-research-reports/national- } \\
\text { land-use-and-cover }\end{array}$ \\
\hline $\begin{array}{l}\text { Land Categories Map of } \\
\text { the U.S.S.R. }\end{array}$ & $\begin{array}{l}\text { Compilation of } \\
\text { different sources from } \\
\text { land cadastre } \\
\text { inventory }\end{array}$ & Not reported & Former U.S.S.R. & 1:4.000.000 & 1991 & $\begin{array}{l}\text { Land cover } \\
\text { (IIASA-LUC Former } \\
\text { U.S.S.R.) }\end{array}$ & Vector & $\begin{array}{l}\text { http://webarchive.iiasa.ac.at/Research/FOR/russia_c } \\
\text { d/download.htm\#download }\end{array}$ \\
\hline $\begin{array}{l}\text { National Land Cover } \\
\text { Database }\end{array}$ & $\begin{array}{l}\text { Based on Landsat } \\
\text { TM satellite imagery }\end{array}$ & \begin{tabular}{|l|}
$2001: 79 \%$ \\
2006: $78 \%$
\end{tabular} & United States & $30 \mathrm{~m}$ & $\begin{array}{l}\text { 1992, 2001, } 2006 \text { and } \\
2011\end{array}$ & $\begin{array}{l}\text { Land cover } \\
\text { (modified Anderson } \\
\text { LCCS) }\end{array}$ & Raster & https://ta.cr.usgs.gov/NLC \\
\hline
\end{tabular}




\section{DATA FROM EARTH OBSERVATION SYSTEMS}

\subsection{Global datasets}

\section{Global Land Cover Classification}

Global Land Cover Classification is a product generated by the Department of Geography of University of Maryland using imagery from the Advanced Very High Resolution Radiometer (AVHRR) satellites acquired between 1981 and 1994. A supervised classification approach was implemented, requiring data to train and validate the algorithm. High-resolution Landsat data provided the basis to derive training data through visual interpretation of the vegetation on the ground. The locations of these training sites were then identified in the AVHRR data, which provided global coverage at a temporal frequency sufficient to characterise seasonal dynamics of the vegetation. Finally, the global land cover classification was derived with a decision tree classifier using the training data and metrics for a single year (1984).

This product is currently available for download at three spatial resolutions: 1 degree, $8 \mathrm{~km}$ and $1 \mathrm{~km}$. 14 land cover types are distinguished, based on those defined by the International Geosphere Biosphere Programme (IGBP) classification system (see Annex A.1), albeit with some differences. An accuracy level between $81 \%$ and $90 \%$ was assessed based on a $20 \%$ sample of the training data validation data (De Fries et al. 1998). However, it must be kept in mind that since the validation data is derived from the same database, the accuracy assessment is expected to be biased when compared to assessments from truly independent validation data.

\section{Global Land Cover Characterization}

Global Land Cover Characterization (GLCC) is a series of global land cover classification datasets resulting from a joint initiative between the U.S. Geological Survey (USGS), the University of NebraskaLincoln (UNL), and the European Commission's Joint Research Centre (JRC). A classification tree approach was implemented to generate the maps, based on the classification of $1 \mathrm{~km}$ AVHRR 10-day NDVI composites imagery collected from April 1992 through March 1993. Multi-temporal AVHRR metrics were used to predict class memberships. Minimum annual red reflectance, peak annual Normalised Difference Vegetation Index (NDVI), and minimum channel three brightness temperature were among the most used metrics, complemented with ancillary data sources such as digital elevation data, ecoregions interpretation, and country- or regional-level vegetation and land cover maps. Besides the IGBP Land Cover classification, the following classifications are also available in the GLCC database:

- Global Ecosystems (96 classes);

- $\quad$ USGS Land Use/Land Cover System (24 classes);

- $\quad$ Simple Biosphere Model (20 classes);

- $\quad$ Simple Biosphere 2 Model (11 classes);

- Biosphere Atmosphere Transfer Scheme (20 classes);

- Vegetation Lifeform (8 classes).

The database was developed on a continent-by-continent basis, with each dataset containing unique elements based on the geographic aspects of the specific continent. All datasets are available for download both at the continental and at the global levels, at $1 \mathrm{~km}$ spatial resolution. Two versions of the database are available: the first (version 1.2) has been subjected to a formal accuracy assessment; the second (version 2.0) results from the changes following the suggestions for additions and improvements given by users of the first version, but no formal accuracy assessment has been conducted. In the first version, the agreements on all classes varied from an average of $65 \%$, when viewing all pixels, to an average of $82 \%$ when viewing only those consisting of greater than $90 \%$ one class within the high-resolution independent 
datasets (Hansen et al., 2000). Depictions of forests, woodlands and areas of mechanised agriculture are in general agreement with other sources of information. Forest and non-forest areas were distinguished with an agreement level ranging from 81 to $92 \%$. On the other hand, classes such as low biomass agriculture and high-latitude broadleaf forest are not. Comparisons of the regional product with regional digital land cover maps derived from high-resolution data reveal general agreement, except for temperate pastures within areas of agriculture.

\section{Global Land Cover 2000}

Global Land Cover 2000 (GLC 2000) is a product developed by the Global Vegetation Monitoring unit of European Commission's JRC, in collaboration with a worldwide network of regional partners. More than 30 research teams have been involved, contributing to 19 regional windows that were posteriorly harmonised and mosaicked into a global dataset using a standardised legend. All regional products were based on a dataset of 14 months of pre-processed daily global data composites acquired by the Vegetation 1 instrument on board of SPOT 4 satellite, from 1st November 1999 to 31 December 2000 at $1 \mathrm{~km}$ resolution. The GLC2000 project uses the FAO Land Cover Classification System (LCCS, see Appendix A.2). The LCCS is a hierarchical classification which allowed each regional partner to describe the land cover classes at the thematic detail best suited to their region of expertise, while following a standardised classification approach. In turn, the LCCS also allowed the regionally defined legends to be translated into more generalised global land cover classes for the GLC2000 global product, thus creating a consistent global land cover classification based on regional expert knowledge. The datasets are available for download both at the regional and global level.

A quantitative accuracy assessment was performed for the North American window, in which an equalised random sample of 7 land cover classes was compared to ancillary data sources such as the National Land Cover Data (NLCD) and Landsat $\mathrm{ETM}^{+}$(Giri and Zhu, 2003). It was estimated an overall accuracy of $66.4 \%$, up to $68.6 \%$ after smoothing. For the global dataset, no formal accuracy assessment was conducted. Instead, a specific method termed as agreement scoring was developed to compare the different regional windows in overlapping pixels and see how well the different classifications correspond (Fritz et al., 2003). Although agreement scoring cannot be considered as an accuracy assessment, it can give an indication of the quality of the maps, depending on the level of agreement in the overlapping areas. It could be concluded that Asia performs overall quite badly since it has a low agreement score with all the other overlapping areas. The European windows rank relatively high, with the exception of the comparison between the North Eastern European and Eurasian window, due to differences in the hierarchical classification of agricultural land, which has a high proportion in both windows.

\section{MODIS Land Cover}

MODIS Land Cover is a series of annual global land cover datasets derived from Moderate Resolution Imaging Spectroradiometer (MODIS) observations by NASA's Terra and Aqua spacecraft. This project is part of NASA's Advancing Collaborative Connections for Earth System Science (ACCESS) program, with the collaboration of the Joint Global Change Research Institute and the Global Land Cover Facility of the University of Maryland. The land cover maps are generated using a supervised artificial neural network classification in conjunction with decision tree classifier, exploiting a global database of training sites interpreted from high-resolution Landsat TM imagery in association with ancillary data (Friedl et al., 2002). The algorithm of the latest collection of MODIS Land Cover products (MODIS Collection 5 Global Land Cover) includes an element to reduce year-to-year variability of classification results not associated with land cover change, particularly in classes that are ecologically proximate, due to poor spectral-temporal separability in MODIS data (Friedl et al., 2010). MODIS land cover products use the IGBP classification system and are available for every year in the period $2000-12$ as mosaics at $500 \mathrm{~m}$ spatial resolution or as spatially aggregated global datasets at 5 ' and $0.5^{\circ}$ resolution. 
A cross-validation analysis using the training database was performed for the year 2005 of the latest collection, indicating an overall accuracy of $74.8 \%$ for all classes (Friedl et al., 2010). However, open shrublands, woody savannahs and savannahs appeared to have low producer accuracies, while mixed forests, closed shrublands, savannahs and woody savannahs, grasslands and agricultural mosaic showed low user accuracies. ${ }^{4}$ On the other hand, the forest classes showed generally good accuracies, as well as agriculture. Water, snow and ice, and barren and sparsely vegetated classes showed very high user and producer accuracies. A separate analysis was conducted for urban areas using a large sample of independent validation sites (Schneider et al., 2009) indicating an accuracy of 93\% at the pixel level and a high level of agreement at the city scale $\left(\mathrm{R}^{2}=0.90\right)$ for this class. Confusion matrix analyses showed that confusion between savannahs and woody savannahs is substantial, woody savannahs are also confused with forest classes, and agricultural mosaic and open shrublands are confused with the closed shrublands, grasslands, and barren and sparsely vegetated classes. These results seem to demonstrate that classification errors are mostly occurring among functionally similar classes that encompass ecological and biophysical gradients.

\section{SYNMAP}

Synergetic land cover product (SYNMAP) is a global land cover product with 48 classes at $1 \mathrm{~km}$ spatial resolution, reflecting global land covers around year 2000 (Jung et al., 2006). It is based on different global land cover products, namely the Global Land Cover Characterization Database (GLCC), GLC2000, and the 2001 MODIS Land Cover product. The method to merge the existing products into a desired classification legend followed the idea of convergence of evidence to generate a 'best-estimate' data set using fuzzy agreement. Affinity scores defined for life form, leaf type, and leaf longevity, linking the defined legend classes with the legend classes of the original products were defined to approximate the thematic distance of the classes. The calculation of the combined map was then done in two steps: 1) determining the dominant life forms; 2) estimating the leaf attributes if a tree component is present in the life form assemblage. SYNMAP has improved characteristics for land cover parameterisation of the carbon cycle models, by using a legend with classes defined in terms of plant functional type mixtures including definitions of leaf type and longevity for each class with a tree component, thus reducing land cover uncertainties in carbon budget calculations.

When comparing SYNMAP with GLCC, GLC2000 and MODIS land cover products, it can be concluded that SYNMAP improves the agreement with all other land cover products. However, no formal validation has been performed and therefore no conclusions can be made regarding its overall accuracy.

\section{GlobCover}

The GlobCover project is built on collaboration between the European Space Agency (ESA), the European Environment Agency (EEA), FAO, GOFC-GOLD, IGBP, the European Commission's JRC, and UNEP. The project aims to deliver $300 \mathrm{~m}$ resolution global composites and land cover maps through automated classification of satellite imagery collected by the MERIS sensor on board of the ENVISAT satellite mission. ESA makes available the land cover maps, which so far cover two periods: December 2004 - June 2006 and January - December 2009. The GlobCover classification is compatible with the LCCS system, with 22 land cover types that are comparable all over the world.

\footnotetext{
${ }^{4}$ Accuracy in land cover and land use data is usually described as the percentage of pixels that are classified correctly in comparison with a trusted reference dataset. User accuracy corresponds to the error of commission and denotes the percentage of grid cells that are correctly classified as belonging to a specific type of land use relative to the total number of grid cells classified as belonging to that use in the land use dataset. Producer's accuracy corresponds to error of omission (or exclusion) and documents the percentage of grid cells that are correctly classified as belonging to a certain land use type relative to the 'actual' number of grid cells belonging to that use in the reference dataset.
} 
Product description and methods of data collection, processing and validation of Globcover 2005 and 2009 are extensively documented in Bicheron et al. (2008) and Bontemps et al. (2011), respectively. Both datasets have been quantitatively assessed by regional experts against an independent validation database. For GlobCover 2009, the overall accuracy weighted by the class area reached 67.5\% using 2190 points globally distributed and including homogeneous and heterogeneous landscapes. This accuracy is slightly lower than that of GlobCover 2005 product, which reached 73\%. This can be due to the fact that the dominance between the different land cover types was taken into account when interpreting the mosaic classes in GlobCover 2009, a criterion that was not considered in 2005 since it was not included in the validation dataset. It must be taken into account that the quality of GlobCover products varies according to the thematic class and region of interest. Land cover classes such as bare areas, rainfed and irrigated croplands, closed broadleaved evergreen forest, water bodies and snow appeared to be quite accurately mapped. On the other hand, classes such as urban areas, sparse vegetation and herbaceous vegetation can be affected by errors. Furthermore, the lack of a short-wave infrared channel in the MERIS sensor contributes to misclassifications in tropical forests, particularly flooded forests. From the end-users point of view, too many mosaic classes appeared to have been mapped, limiting the thematic sharpness of the GlobCover product. In some regions of the world, satellite data coverage was lower than elsewhere (e.g. due persistent clouds coverage), particularly in South America, North East of America, Central Siberia, North-East of Asia, Korea, Philippines and Malaysia and Central Africa. Therefore, the quality of the land cover products should be expected to be lower in these regions.

\section{Climate Change Initiative Land Cover (CCI-LC)}

The Climate Change Initiative Land Cover (CCI-LC) products result from the collaboration between the Université Catholique de Louvain (UCL), Brockmann Consult, University of Jena, the Joint Research Centre and Wageningen University. A three-epoch series of global land cover maps has been produced and released at 300m spatial resolution, with each epoch covering a 5-year period (2008-2012, 2003-2007, 1998-2002). These maps were produced using a multi-year and multi-sensor strategy. First, the entire 2003-2012 MERIS Full and Reduced Resolution (FR and RR) archive was used as input to generate a 10year 2003-2012 global land cover map. This 10-year product has then served as a baseline to derive the 2010, 2005 and 2000 maps using back- and up-dating techniques with MERIS and SPOT-Vegetation time series specific to each epoch. The classification module capitalised on the GlobCover unsupervised classification chain developed by UCL-Geomatics, which was improved by adding machine learning classification steps and developing a multiple-year strategy. The typology was defined using the LCCS system, aiming to be as much as possible compatible with the GLC2000, GlobCover 2005 and 2009 products. For a complete overview on the production of CCI-LC maps, see Kirches et al. (2014). Besides land cover maps, the following products were also made available:

- the full archive (2003-2012) of MERIS Full Resolution time series pre-processed in 7-day composites;

- three global land cover seasonality products describing the vegetation greenness, the snow and the burned areas occurrence dynamics;

- a global map of open and permanent water bodies at $300 \mathrm{~m}$ spatial resolution.

An accuracy assessment has been performed for the 2010 epoch, indicating a weighted-area overall accuracy of $74.1 \%$. Classes like "bare areas", "broadleaved evergreen forest", "water" and "snow and ice" were found quite accurately mapped, which is surely not surprisingly, as these classes are homogeneous, unambiguous and recognisable. What was more unexpected - and therefore quite a good result - was the high accuracy associated with the cropland and forest classes. On the other hand, classes such as shrubland, grassland, sparse vegetation and wetlands can be affected by misclassification errors. Similarly to GlobCover products, the map varies according to the region of interest, depending on the number of valid observations available. 


\section{Global Land Survey}

The Global Land Survey (GLS) is a collection of Landsat $30 \mathrm{~m}$ resolution imagery resulting from a partnership between the U.S. Geological Survey (USGS) and the National Aeronautics and Space Administration (NASA). GLS aims to support measurement of Earth's land cover, replacing and improving upon GeoCover (firstly collected into three epochs around 1975, 1990 and 2000) by using more accurate elevation data for terrain correction and also by adding another epoch centred around 2005 (Gutman et al., 2008). GLS collection uses imagery from all seven Landsat sensors: the 1975 epoch includes images from the MSS sensors of Landsat satellites 1-4; the 1990 epoch contains images from mostly the Landsat 5 TM, but also some ETM+ from Landsat 7; for 2005, images were captured from a variety of sensors, mainly Landsat-5 TM and Landsat-7 ETM+, but also EO-1 ALI where Landsat-5 or Landsat-7 imagery was not available, particularly over oceanic islands, in order to obtain near-complete global coverage. The GLS scenes are distributed as band separate, thus they do not consist in a land cover classification product. However, land cover and land cover change products based on GLS have been developed, such as:

- Landsat Tree Cover Continuous Fields, which contains estimates of the percentage of horizontal ground in each $30 \mathrm{~m}$ pixel covered by woody vegetation greater than 5 metres in height, available for 2000 and 2005;

- Landsat Forest Cover Change, which represents global changes in forest cover at $30 \mathrm{~m}$ resolution between 2000 and 2005 epochs.

\section{FROM-GLC 30 m}

FROM-GLC (Finer Resolution Observation and Monitoring of Global Land Cover) is a collection of $30 \mathrm{~m}$ resolution global land cover maps, resulting from collaboration between several universities and institutes in China and the United States. The maps were produced using Landsat Thematic Mapper (TM) and Enhanced Thematic Mapper Plus (ETM+) imagery centred around 2006. A unique land cover classification system was developed that allows to crosswalk to the existing FAO-LCCS and IGBP systems Four classifiers have been employed to create the land cover maps: the conventional maximum likelihood classifier (MLC), J4.8 decision tree classifier, Random Forest (RF) classifier and support vector machine (SVM) classifier (Gong et al., 2013). The SVM produced the highest overall classification accuracy of 63.72\% assessed when compared against test samples, with RF (59.8\%), J4.8 (57.9\%), and MLC (53.9\%) ranking somewhat lower. When using a subset of our test samples representing homogeneous areas greater than $500 \mathrm{~m} \times 500 \mathrm{~m}$, the SVM showed an accuracy of $71.5 \%$.

Besides the original FROM-GLC dataset, four additional datasets are also available for download:

- $\quad$ FROM-GLC-seg (Yu et al., 2013a), an improved version of FROM-GLC produced by integrating multi-resolution datasets, including Landsat TM/ETM+ (30m), MODIS EVI time series (250m), bioclimatic variables $(1 \mathrm{~km})$, global DEM $(1 \mathrm{~km})$, and soil-water variables $(1 \mathrm{~km})$. FROM-GLCseg used the same training/test samples as FROM-GLC, and followed the same classification system with slight modifications. The RF classifier was used and achieved better overall accuracy $64.42 \%$, particularly mapping accuracies for cropland, forest and barren land were improved. However, they are slightly lower for water bodies and snow/ice land cover types because coarser resolution MODIS (250 metre) and Bioclimatic, DEM, Soil-Water variables (1 km) are not ideal for recognising small-scale objects.

- $\quad$ FROM-GLC-agg (Yu et al., 2014a), a further improvement of previous versions by aggregating FROM-GLC and FROM-GLC-seg, together with two coarse resolution impervious maps, namely Nighttime Light Impervious Surface Area and MODIS urban extent. FROM-GLC-agg has a 
significantly better overall accuracy (65.51\%) than the other datasets, while for individual land cover types accuracies have been increased or better balanced.

- $\quad$ FROM-GC (Yu et al., 2013b), a cropland extent product developed with FROM-GLC, FROMGLC-ag and a 250-m cropland probability map. A common land cover validation sample database (Zhao et al., 2014) was used to determine optimal thresholds of cropland probability in different parts of the world to generate a cropland/noncropland mask according to the classification accuracies. A decision tree was then applied to combine two $250 \mathrm{~m}$ cropland masks with FROM-GLC-agg. For the smallest difference with country-level cropland area in Food and Agriculture Organization Corporate Statistical (FAOSTAT) database, a final global cropland extent map was composited from the FROM-GLC, FROM-GLC-agg, and two masked cropland layers. Africa, South America, Southeast Asia, and Oceania are the regions with large discrepancies with the FAO survey.

- FROM-GLC-Hierarchy (Yu et al., 2014b), a land cover dataset collection with multi-resolution, specifically $30 \mathrm{~m}, 250 \mathrm{~m}, 500 \mathrm{~m}, 1 \mathrm{~km}, 5 \mathrm{~km}, 10 \mathrm{~km}, 25 \mathrm{~km}, 50 \mathrm{~km}$ and $100 \mathrm{~km}$. The $30 \mathrm{~m}$ base map was improved from FROM-GLC-agg with additional coarse resolution datasets such as MCD12Q1 and GlobCover2009, to reduce land cover type confusion. Around 1.1\% pixels were replaced by coarse resolution products. Validation based assessments indicate the accuracy for land cover maps at $30 \mathrm{~m}, 250 \mathrm{~m}, 500 \mathrm{~m}, 1 \mathrm{~km}$ resolutions are $69.50 \%, 76.65 \%, 74.65 \%$, and $73.47 \%$, respectively. The analysis of area-estimation biases for different land cover types at different resolutions suggests that maps at coarser than $5 \mathrm{~km}$ resolution contain at least $5 \%$ area estimation error for most land cover types.

\section{GlobLand30}

GlobeLand30 is a $30 \mathrm{~m}$ resolution global land cover product distributed by the National Geomatics Center of China which depicts dominant land cover classes for years 2000 and 2010 (Jun et al., 2014). Landsat TM/ETM+ imagery was used as the primary data source, supplemented with imagery from the Chinese Environmental and Disaster satellite (HJ-1) for the year 2010 and other ancillary data such as existing global and regional land cover data, global DEM and topographic data, ecological zones data, and online-distributed geospatial data services. The datasets were created by applying a hybrid pixel-objectknowledge-based (POK-based) classification approach (Chen et al., 2014). First, the spatial extent of land features and their structural/contextual information was determined to form land objects. Then, pixel-based classifiers were used to derive variables and to identify the attribute value for any given land object, with the help of available reference data and expert knowledge. Finally, the classified datasets were verified and corrected according to nature-based, culture-based and temporal-constraint knowledge of the geographical distribution of land cover, in order to avoid misclassification issues such as confusion of mountain shadows with surface water due to solar altitude.

The classification system includes 10 land cover types:

- Cultivated land, lands used for agriculture, horticulture and gardens, including paddy fields, irrigated and dry farmland, vegetation and fruit gardens, etc.

- $\quad$ Forest, i.e. lands covered with trees, with vegetation cover over 30\%, including deciduous and coniferous forests, and sparse woodland with cover 10-30\%, etc.

- Grassland, lands covered by natural grass with cover over $10 \%$, etc.

- Shrubland, i.e. lands covered with shrubs with cover over $30 \%$, including deciduous and evergreen shrubs, and desert steppe with cover over $10 \%$, etc.

- Water bodies. Water bodies in the land area, including river, lake, reservoir, fish pond, etc. 
- Wetland, i.e., lands covered with wetland plants and water bodies, including inland marsh, lake marsh, river floodplain wetland, forest/shrub wetland, peat bogs, mangrove and salt marsh, etc.

- Tundra, i.e. lands covered by lichen, moss, hardy perennial herbs and shrubs in the polar regions, including shrub tundra, herbaceous tundra, wet tundra and barren tundra, etc.

- Artificial surfaces, i.e. lands modified by human activities, including all kinds of habitation, industrial and mining area, transportation facilities, and interior urban green zones and water bodies, etc.

- Bareland, i.e. lands with vegetation cover lower than $10 \%$, including desert, sandy fields, bare rocks, saline and alkaline lands, etc.

- $\quad$ Permanent snow and ice, i.e. lands covered by permanent snow, glacier and icecap.

A preliminary accuracy assessment was conducted for year 2010 dataset according to a two-rank sampling strategy, which involved selecting map sheet samples from the global map sheets, followed by a spatially stratified sampling procedure of selected features for each land cover type within each elected map sheet. An area-weighted overall accuracy of $79.26 \%$ was determined, with every land cover achieving a user's accuracy higher than $70 \%$. GlobLand30 was also compared to FROM-GLC and CORINE (see section 1.2.1) datasets. It was found that the quality of GlobeLand30 was at the similar level to CORINE data. It was also found that FROM-GLC fully automated classification product is of much lower quality than POK-classification GlobLand30 product. Particularly, classification errors between shadow and water were quite prevalent.

\section{Global Land Cover-Share}

The Global Land Cover-SHARE (GLC-SHARE) is a land cover database at the global level created by FAO's Land and Water Division in partnership with various partners and institutions. It provides a set of major thematic land cover layers at a resolution of 30 arc-seconds (approximately $1 \mathrm{~km}$ ). National, regional and global land cover datasets with a high and medium resolution were combined and harmonised into one centralised database (see Latham et al., 2014 for a complete list of the datasets used for the creation of the maps). An approach based on the utilisation of the LCCS system was implemented for the harmonisation of the various land cover maps. Eleven land cover classes were created in line with the System of Environmental-Economic Accounting (SEEA), with all legends being translated in the SEEA legend (see Appendix A.3) for the final classification. Land cover classifier elements were used to translate the legends and assign the most adequate classifier values, particularly as class, class unit, minimum, maximum, range and best estimate values of the percentage of each land cover class per grid cell. The results are reported as maps showing the percentage per grid cell of a particular land cover class and as a map with the dominant land cover type per grid cell.

The accuracy of the database was assessed through confusion matrix analysis comparing reference data and the corresponding results of the dominant land cover class. The overall dominant class accuracy is around $80 \%$, although user's and producer's accuracies vary among classes. Producer's and User's Accuracy score relatively poorly (around 50\%) for land use classes such as Herbaceous Vegetation and Sparse Vegetation, while for Cropland and Tree Covered Area they score quite well (around 90\%).

\subsection{Regional datasets}

\section{CORINE Land Cover}

The CORINE Land Cover (Coordination of Information on the Environment - Land Cover, or CLC) refers to a European programme establishing a computerised inventory on land cover and land use of the 28 European Union member states and other European countries. CLC products are based on the photo-interpretation of Landsat ETM+ from IMAGE2000, a satellite imaging program undertaken jointly 
by the Joint Research Centre of the European Commission and the European Environment Agency (EEA) that was produced at country level using a common nomenclature and standard methodology under the coordination and supervision of the EEA. Besides the interpretation of satellite imagery, a number of different topographical and statistical ancillary datasets are also used, depending on the availability at country level. The national land cover maps are then assembled into a seamless European map, resulting in a complete and consistent dataset across Europe (EEA 2006). The datasets are distributed in vector format at an original scale of 1:100 000 with a minimum mapping unit (MMU) of 25 hectares, although the EEA also makes it available in raster format at a $100 \mathrm{~m}$ pixel resolution. CLC uses a highly thematic legend with 44 classes organised in three hierarchical levels, combining both land cover and land use concepts (see appendix A.4). CLC records land cover and land use for a time-series centred on the years 1990, 2000, 2006 and 2012 (under preparation) and has full EU coverage, with many non-EU countries also covered (e.g. EFTA, Balkan countries and Turkey, although the Scandinavian countries and UK are not covered in the 1990 version, and Greece is not yet covered in the 2006 version). Change maps are also available for the periods 1990-2000 and 2000-2006 with an MMU of 5 hectares, thus providing extra spatial detail on land cover and land use change that occurred during each time lapse.

An accuracy assessment carried out for the CLC 2000 map shows that the geometric accuracy is higher than 100 metres and that the thematic accuracy is 87.0\% (EEA 2006). The highest class-level reliability (> 95\%) was obtained for rivers, lakes, industrial and commercial units and discontinuous urban fabric. Arable land and coniferous forest, the two largest classes in the assessed area, also achieved a high level of reliability (between 90-95\%). The lowest class-level reliability (below 70\%) was obtained for sparse vegetation class, thus highlighting the difficulties in interpreting this category. The majority of misclassification errors (78\%) occurred at the hierarchical levels 2 and 3 (though they are not specified in the assessment report). Level 1 misclassification errors mostly occur between agriculture and forest and semi-natural classes. Subjectivity of photo interpretation could be noticed in $18.2 \%$ of the samples, particularly in heterogeneous classes such as agriculture with significant amount of natural vegetation, transitional woodland, shrub, complex cultivation patterns and mixed forest.

Some limitations on the usage of CLC have been found. For instance, the large size of the MMU limits the scope of application of the CLC in the context of urban studies. Given the MMU of the CLC, many small urban areas are actually hidden within the surrounding and dominant patches, leading to underestimation of these land use types. To overcome these issues, a modification of the 2006 version was produced by integrating data from more detailed thematic geo-sources, such as CLC change map, Soil Sealing Layer, Tele Atlas Spatial Database, Urban Atlas, and Water Bodies Data from the Shuttle Radar Topography Mission. The refined version enabled the reduction of the minimum mapping unit to 1 hectare for most of the artificial land use categories and water bodies. In addition, a more consistent classification of the urban areas into three comparable levels of density was achieved. The modified version of the CLC, known as 'CLC-refined', is described in a dedicated paper by Batista e Silva et al. (2013). The JRC intends to undertake again a refinement procedure of the CLC as soon as the 2012 version is released.

\section{North American Land Change Monitoring System}

The North American Land Change Monitoring System (NALCMS) is a joint project between Canada, Mexico and the United States facilitated by the North American Commission for Environmental Cooperation (CEC). The objective of NALCMS is to devise a harmonised multi-scale land cover monitoring framework, which can be applied across North America with high accuracy and meet the specific requirements of each country. NALCMS products are based on imagery collected by MODIS instruments. Mapping was performed by each country using unique data pre-processing and information extraction methodologies. The national products were subsequently assembled into an integrated North America land cover database at a $250 \mathrm{~m}$ spatial resolution. The classification legend is designed in three hierarchical levels using the FAO-LCCS system: Level I and II are common for North America while level 
III is country specific. There are currently two series available for the year 2005 and 2010. This 2010 data set was produced by updating the 2005 data to show land cover changes as determined from more recent data. No changes were mapped in Hawaii because newer data were not available.

An accuracy assessment was performed on the Canadian data at the 12-class IGBP level, using a sample of high-resolution image data in Google Earth, supported by Landsat data. Each sample was interpreted and assigned a primary label, a secondary label and a confidence level. The primary label referred to the most likely class assigned to a pixel according to the interpreter, while the secondary label referred to a second class that could also be considered acceptable. For the primary label only, overall accuracy was nearly 59\%, increasing to $69 \%$ when considering either the primary or secondary label as being correct. For primary labels interpreted with high confidence, overall accuracy increased again to $75 \%$, as a function of greater land cover homogeneity within the reference data footprint and less ambiguity largely due to reference image quality. The analysis of the classification error matrix revealed the sources of spectral confusion among land cover classes. Adjacent forest classes tended to be confused, as well as deciduous forest, shrubland, shrub-covered wetlands, and certain croplands. These classes were difficult to separate with spectral data alone due to all classes being primary broadleaved deciduous. Other issues arose with the herbaceous class, which was either conifer consisting of open treed areas with herbaceous understory, or low biomass croplands. Confusion between herb, shrub, and deciduous was also due to relatively small disturbance patch sizes of cuts. Finally, the lichen/moss class was either herbaceous or wetland according to the reference data, due to the prevalence of both lichen and moss in certain wetlands and the low biomass of both the lichen/moss and herbaceous classes. No formal accuracy assessment has been performed for data products in Mexico and the United States. For the 2010 dataset, change in classification has been found for approximately $1 \%$ of the land surface, thus attribute accuracy was assumed to be essentially the same as for the 2005 dataset.

\subsection{National datasets}

In this section, we review land cover datasets that are produced at the country level. We deliberately refrained from reviewing European countries, since CORINE Land Cover products are created at the country level and made available at a relatively high spatial resolution. For some countries, we were not able to find readily available land cover and land use datasets, which could have been due to e.g. data not being released online, access being restricted, or data being (temporarily) unavailable at the time this review was conducted. However, the (future) availability of data, as well the existence of spatial data infrastructures, was often mentioned in official documents and websites. For these countries (listed alphabetically), we refer to the relevant literature and websites and indicate the prospects for data availability.

\section{OECD member countries}

\section{Australia}

The Australian Land Use and Management (ALUM) program provides a time series of maps depicting land cover in Australia at the national scale with a 1:2 500000 spatial resolution. ALUM uses a modelling approach to integrate agricultural commodity data, AVHRR satellite imagery and other land use information. The classification has six primary classes of land use that are distinguished in the order of generally increasing levels of intervention or potential impact on the natural landscape:

- Conservation and Natural Environments: land is used primarily for conservation purposes, based on the maintenance of essentially natural ecosystems already present.

- Production from Relatively Natural Environments: land is used mainly for primary production based on limited change to the native vegetation. 
- Production from Dryland Agriculture and Plantations: land is used mainly for primary production, based on dryland farming systems.

- Production from Irrigated Agriculture and Plantations: land is used mainly for primary production, based on irrigated farming.

- Intensive uses: land is subject to substantial modification, generally in association with closer residential settlement, commercial or industrial uses.

- Water: although primarily land cover types, water features are regarded as essential to the classification.

Non-agricultural land uses are drawn from existing digital maps covering six themes: topographic features, catchment scale land use, protected areas, world heritage areas, tenure and forest cover. National land use data is available for the years 1992-93, 1993-94, 1996-97, 1998-99, 2000-01, 2001-02 and 200506 years. Year 2010-11 is expected to be soon available. Data is also available at the catchment level with a spatial resolution of 1:250,000 but not for every year. A formal accuracy assessment of the data series could not be found.

The National Dynamic Land Cover is a land cover map based on MODIS EVI composites currently available for the period 2000-2008 with 250 m resolution. Its legend is based on FAO-LCCS classification system. No formal accuracy assessment has, so far, been conducted. Time series depicting land cover for every year between 2000 and 2010 are expected to become soon available.

Canada

The Canada Land Cover map is actually available in combination with a land cover map of Alaska. Each land cover map utilised different types of AVHRR imagery and derived NDVI datasets. This dataset merges the two datasets into one land cover map at $1 \mathrm{~km}$ resolution utilising the Alaska Interim land cover class system. The land cover map of Canada resulted from a joint effort between NBIOME scientists at the Laurentian Forest Research Centre, Canadian Forest Service and the Canada Centre for Remote Sensing (Cihlar and Beaubien, 1998).

The Canada Land Cover circa $\mathbf{2 0 0 0}$ is the result of vectorisation of raster thematic data originating from classified Landsat 5 and Landsat 7 satellite imagery for agricultural and forest areas of Canada, and for Northern Territories (NRC, 2014). The forest cover was produced by the Earth Observation for Sustainable Development (EOSD) project, an initiative of the Canadian Forest Service with the collaboration of the Canadian Space Agency and in partnership with the provincial and territorial governments. The agricultural coverage is produced by the National Land and Water Information of Agriculture and Agri-Food Canada. Northern Territories land cover was realised by the Canadian Centre of Remote Sensing. Land Cover data was classified according to a harmonised legend based on the legend described in EOSD Land Cover Classification Legend Report. This product aimed to produce a Canadian integrated Land Cover from the various available classified satellite data. The Land Cover base dating extended from 1996 to 2005, with 80\% of the Land Cover base coming from 1999 to 2001, thus being defined as circa 2000.

Chile

Catastro de los Recursos Vegetacionales Nativos de Chile - the Cadastre of Native Vegetation Resource of Chile is a time series of land cover datasets produced by the National Forest Corporation at 1:30 000 scale. The maps were originally derived from the interpretation of panchromatic aerial photography, being currently based on SPOT 5 and FORMOSAT-2 satellite imagery. The datasets cover the whole country, being divided in mosaics of 15 regions. Data series are available for 1997, 2001, 2007 
and 2011, although the exact year of data collection might differ among regions. The datasets are in vector format, with each polygon being characterised not only in terms of land cover, but also land use, property rights, forest category, forest establishment and reforestation, biomass, carbon, forest fires and forestry resource extraction (FAO, 2010). At the moment, only the dataset for 2011 seems to be available for download in the national spatial data infrastructure website ${ }^{5}$. No formal accuracy assessment report could be found regarding this dataset.

Israel

A number of websites reference the availability of geographic information data, e.g.:

- $\quad$ The Central Bureau of Statistics, Geographic Information Centre ${ }^{6}$

- $\quad$ GISrael, a geographic information database of Israel (in Hebrew and English) ${ }^{7}$.

However, these data sources are not readily available and seem to be available only through purchase. The Survey of Israel, the government agency for mapping, geodesy, cadastre and geo-informatics, is currently conducting several initiatives regarding the development of a national spatial infrastructure, such as launching a new geo-portal enabling web services and creating the national Land Information Centre for online information sharing among professionals (see Srebro et al., 2010). However, no information could be found regarding the state of development of these initiatives.

Japan

Japan's National Land Numerical Information (NLNI) is a database with time series on surface area of land use classes based on status of nationwide land use, for the years 1976, 1987, 1991, 1997, 2006 and 2009. NLNI is based on a large number of data sources, including 1:25000 and 1:50000 topographical maps, 1:25000 current land use status maps, land use measurement maps, land use classification standard tables and satellite imagery. Different methods were used to derive the maps for each year. For the 1976 and 1987 maps, datasets were created using 1:25000 topographical maps and the results were converted to the NLNI uniform format (old format) to generate land use mesh data. For the 1991, 1997 and 2006 maps, image data from satellite remote sensing (Landsat) underwent geometric correction and Normalised Vegetation Index (NVI) calculations. For 2009, image data from satellite TERRA (Aster) and ALOS remote sensing underwent geometric correction and NVI calculations. The whole country area is covered in $1 \mathrm{~km}$ mosaics, which are subdivided into $100 \mathrm{~m}$ (1/10 fragmentation) mesh units. In each mesh, the attribute table indicates the surface area of every corresponding land use class (values in $\mathrm{m}^{2}$ ). No accuracy assessment report could be retrieved.

Mexico

Uso del Suelo y Vegetation is a time series of land cover of Mexico at a scale of 1:250 000 produced by the National Institute of Statistics, Geography and Informatics for the years 1976, 1993, 2000, 2007 and 2011. The 1976 dataset was produced by digitising an existing map derived from the interpretation of aerial photography, while the remaining datasets were derived from the interpretation of Landsat TM satellite imagery. The classification system of the database presents a hierarchical organisation from the high level of community to the low level of plant formation. This classification was obtained by aggregating classes in order to make it compatible with the National Forest Inventory database (IFN2000),

\footnotetext{
${ }^{5}$ http://ide.mma.gob.cl/

${ }^{6}$ http://gis.cbs.gov.il/main_gis/-eng_gis.htm

${ }^{7}$ http://www.gisrael.co.il/
} 
taking into account biological classification criteria such as phenology and floristic composition, and geographic criteria, particularly the spectral response of inputs derived from remote sensing.

No formal accuracy assessment of the time series could be found. At the moment, only the dataset for year 2011 is available for download. The datasets for the years 1976, 1993 and 2000 are currently not available, but they can be visualised at the Mexican National Institute of Ecology and Climate Change website $^{8}$ as well as the transition matrices for the periods of 1976-1993 and 1976-2000.

New Zealand

The Land Use and Carbon Analysis System (LUCAS) Land Use map (LUM) is a time series of land cover and land use thematic databases of New Zealand based on FAO-LCCS system, covering mainland New Zealand, the near shore islands and the Chatham Islands, for the year 1990, 2008 and 2012 (NZME, 2012). The 1990 land use map was derived from standardised 30m spatial resolution Landsat 4 and Landsat 5 satellite imagery taken between 1988 and 1993. These images were used for the automated mapping of woody biomass and the classification of woody land use classes. This classification process was further validated and improved using 15m resolution Landsat 7 ETM+ imagery acquired in 2000-2001, and SPOT 2 and 3 data acquired in 1996-1997. The 2008 land use map was derived from $10 \mathrm{~m}$ spatial resolution SPOT 5 satellite imagery taken during the summer periods between 2006 and 2008, processed into standardised reflectance images using the same approach as for the 1990 imagery. A combination of aerial photography, Landsat satellite imagery and field verification was used to identify where deforestation has occurred. SPOT 5 satellite imagery was again used to create the 2012 land use map. All imagery was preprocessed as for the 2008 map; however, in this instance, the 2008 and 2012 standardised imagery was combined into an image stack in order to detect areas of change. Areas of forest loss were extracted and underwent a separate deforestation mapping process, while the remaining areas of change were mapped directly into the 2012 map. Areas of confirmed deforestation were finally integrated into the 2012 land use map.

An independent accuracy assessment was conducted for 2012 map, by comparing randomly-selected points across New Zealand with $1.5 \mathrm{~m}$ resolution SPOT Maps image mosaic (NZME, 2014). The overall map accuracy was assessed to be $95.2 \%$, with user's and producer's accuracies all above $90 \%$ except for the producer's accuracy of the grassland with woody biomass class (59.9\%) and wetland classes (85.0\%).

\section{Korea}

The National Geographic Information Institute (NGII) is the governmental body responsible for building and maintaining the national framework database. On NGII's website, extensive reference is made to plans regarding the construction of a National Geographic Information System (NGIS) and the Korea Land Information System (KLIS). ${ }^{9}$ However, we were not able to find the related websites, which are likely only available in Korean. As a result, no country-specific data sources could be retrieved for Korea.

\section{United States}

The National Land Cover Database (NLCD) is a 21-class land cover classification scheme based on Anderson Land Cover Classification System (see Annex A.5) created by the Multi-Resolution Land Characteristics (MRLC) Consortium that has been applied consistently across the United States at a spatial resolution of 30 metres. It is based primarily on the unsupervised classification of Landsat TM satellite data, complemented by other ancillary data sources such as topographic maps, census and agricultural

\footnotetext{
${ }^{8}$ http://mapas.inecc.gob.mx

${ }^{9}$ http://www.ngii.go.kr/en/contents/contentsView.do?rbsIdx=61
} 
statistics, soil characteristics, and other types of land cover and wetland maps. These include a circa 1992 conterminous U.S. land cover dataset with one thematic layer (NLCD 1992), a circa 2001 50-state/Puerto Rico updated United States land cover database (NLCD 2001) with three layers including thematic land cover, percent imperviousness, and percent tree canopy, and a 1992/2001 Land Cover Change Retrofit Product. The circa 2006 NLCD land cover product (NLCD 2006) was conceived to meet user community needs for more frequent land cover monitoring (moving to a 5-year cycle) and to reduce the production time between image capture and product release.

An accuracy assessment has been performed on four primary products: 2001 land cover, 2006 land cover, land cover change between 2001 and 2006, and impervious surface change between 2001 and 2006 (Wickham, 2013). The accuracy assessment was conducted by selecting a stratified random sample of pixels with the reference classification interpreted from multi-temporal high resolution digital imagery. The NLCD Level II (16 classes) overall accuracies for the 2001 and 2006 land cover were 79\% and 78\%, respectively, with Level II user's accuracies exceeding $80 \%$ for water, high density urban, all upland forest classes, shrubland, and cropland for both dates. Level I (8 classes) accuracies were 85\% for NLCD 2001 and $84 \%$ for NLCD 2006. The high overall and user's accuracies for the individual dates translated into high user's accuracies for the 2001-2006 change themes of water gain and loss, forest loss, urban gain, and the no-change themes for water, urban, forest, and agriculture (above 95\%). The main factor limiting higher accuracies for the change reporting themes appeared to be the difficulty in determining the context of grass and distinguishing open space from other classes.

\section{OECD accession countries}

\section{Colombia}

A number of websites mention the existence of land cover and land use data sources, see e.g.:

- Infrastructura Colombiana de Datos Espaciales (in Spanish) ${ }^{10}$;

- Instituto Geografico Agustino Codazzi (in Spanish) ${ }^{11}$.

Although maps are available for download in pdf format and for visualisation in webportals (thus indicating that relevant data sources exist), we were not able to retrieve datasets suitable for being used in GIS environment.

\section{Costa Rica}

1. Costa Rica's National Institute of Geography has been mandated to set up the national spatial data infrastructure - in Spanish, Infraestructura de Datos Espaciales de Costa Rica (IDECOR). However, the lack of an operating website seems to indicate that this process is still at an early stage. Several maps seem to be available as jpg files in the website of the Universidad Nacional de Costa Rica, including agricultural land use and forest land cover maps ${ }^{12}$. Although the existence of these maps appears to indicate that relevant data sources exist, they might not be readily available in the appropriate GIS format.

\footnotetext{
${ }^{10}$ http://www.icde.org.co/web/guest/mapas_geoservicios

${ }^{11}$ http://geoportal.igac.gov.co/ssigl2.0/visor/-galeria.req?mapaId=76

${ }^{12}$ http://www.mapoteca.geo.una.ac.cr/index.php/-remository.html?func=select\&id=7
} 


\section{Other G20 countries}

\section{Argentina}

PNECO's Cobertura del suelo de la Republica Argentina - a land cover map of Argentina at the 1:500,000 scale has been produced for the period of 2006-2007 under the Plano Nacional de Ecorregiones (PNECO) project. The map is based on MODIS TERRA and LANDSAT TM satellite imagery and makes use of a hierarchical legend system based on the FAO-LCCS system. The project report (see INTA, 2009) indicates plans for making the dataset available for download, but so far it is only available for visualisation in GeoINTA, the spatial database infrastructure of the National Institute of Agriculture. ${ }^{13}$

\section{Brazil}

The Mapeamento Sistemático do Uso da Terra data series is a collection of land use maps produced under the Land Use and Land Cover project of the Geosciences Division of the Brazilian Institute of Geography and Statistics. The maps are produced at 1:250,000 scale through the interpretation of Landsat 7 ETM+ satellite imagery, using a classification inspired in EU's CORINE Land Cover data series. However, the available mosaics do not cover the entire country and have been collected in different time periods, some of them in 2003, others in 2007. Therefore, the use of this database as a country-specific data source for the computation of indicators is rather limited due to its incompleteness.

\section{China (People’s Republic of)}

The China Land Cover is a database at 1:10,000,000 resolution based on Landsat TM and ETM 30m satellite imagery, covering China for the year 1990, 1995, 2000, 2005 and 2008. The data series are provided by the Data Center for Resources and Environmental Sciences of the Chinese Academy of Sciences. However, it was not possible to download data from the website, which is in Chinese and might require registration. ${ }^{14}$

India

Several data sources seem to have been produced and put available in the National Spatial Database website. ${ }^{15}$ However, access to the services appears to be password protected and for government-togovernment use only.

\section{Indonesia}

The development of a national spatial data infrastructure - in Bahasa, Badan Informasi Geospasial appears to be ongoing through cooperation between the Indonesian Geospatial Information Agency with Japan International Cooperation Agency. See for example:

- Badan Informasi Geospasial website (in Bahasa); ${ }^{16}$

- Article in ESRI website about the development of a spatial data infrastructure in Indonesia. ${ }^{17}$

\footnotetext{
${ }^{13}$ http://geointa.inta.gov.ar/visor/?p=82

${ }^{14}$ http://www.resdc.cn/data.aspx?DATAID=99

${ }^{15}$ http://gisserver.nic.in/nsdb/

${ }^{16}$ http://www.bakosurtanal.go.id/

${ }^{17}$ http://esriindonesia.co.id/case-studies/indonesias-national-spatial-data-infrastructure-sad-122
} 
However, at the moment no data source seems to be available for download through this platform.

\section{Russian Federation}

The Federal Service for State Registration, Cadastre and Cartography (FSSRCC) is the federal agency in the Russian Federation (hereafter 'Russia') responsible for the organisation of the spatial data infrastructure. FSSRCC makes available a geoportal that appears to enable the visualisation of several spatial data sources. ${ }^{18}$ However, the website is in Russian, and therefore it was not possible to assess its potential capabilities on providing access to land cover and land use data sources.

The Land Categories Map of the U.S.S.R is a land cover map made available by IIASA-LUC's project Georeferenced Database of the Former U.S.S.R (Stolbovoi et al., 1997). This dataset results from the compilation of different sources from land cadastre inventory, such as series of political-administrative and administrative maps, regional physical and thematic maps, topographic maps and statistic data.

\section{Saudi Arabia}

The General Commission for Survey (CCS) is Saudi Arabia's leading national organisation in surveying, mapping, charting, geographical information and hydrographic survey. GCS is responsible for setting up the national spatial data infrastructure, as well as the geoportal enabling the visualisation of several topographic and hydrographic maps. ${ }^{19}$ However, GIS data availability is still rather limited, with maps available for download only in pdf format.

\section{South Africa}

National Land Use and Cover: The National Geo-spatial Information (NGI) of the Department of Rural Development and Land Reform is South Africa's national mapping organisation. NGI is currently building a national spatial data infrastructure, as well as embarking on a programmatic approach to national land cover and land use mapping. ${ }^{20}$ However, it is not known when the first data series will become available. For additional information, see RDLR (2009).

\section{LAND SURVEY AND ADMINISTRATIVE DATA}

Next, we review the land cover and land use-related data available in census databases at different levels of aggregation. The aim is to examine whether and how land survey and administrative data can serve as an alternative data source.

\subsection{Global databases}

\section{FAOSTAT}

The Food and Agriculture Organisation of the United Nations (FAO) is responsible for the FAOSTAT database, which provides a time-series of data relating to food, agriculture and land use. This data is mostly based upon country specific statistical data sources. FAOSTAT Land use statistics contain data on Country area (including area under inland water bodies), Land area (excluding area under inland water bodies), Agricultural area, Arable land and Permanent crops, Arable land, Permanent crops, Permanent meadows and pastures, Forest area, Inland water, Other land and Area equipped for irrigation. Data are available

\footnotetext{
${ }^{18}$ http://maps.rosreestr.ru/PortalOnline

19 http://geoportal.gcs.gov.sa/GCS/WebPages/Map/-FundyViewer.aspx?THEME=Emerald\&Language=en-US

${ }^{20}$ http://www.ngi.gov.za/index.php/technical-information/publications-research-reports/-national-land-use-and-cover
} 
from 1961 onwards for more than 200 countries. The annual FAO Land Use and Irrigation questionnaire is the primary source of data on countries' land use. The data collected from the questionnaires are from official national sources. From 2001, the land use questionnaire also includes further information on areas that are actually irrigated and on land use sub-categories such as Temporary crops, Temporary meadows and pastures, Fallow land, Permanent meadows and pastures cultivated and naturally growing, as well as Organic land (starting year 2004) and Area of arable land and permanent crops under protective cover (starting year 2007). Starting in 2010, the questionnaire also includes items on land used for organic production and land in conversion to organic production, namely agricultural area certified organic, agricultural area in conversion to organic, arable area organic, arable area in conversion to organic, permanent crops area organic, permanent crops in conversion to organic, permanent meadows and pastures area organic and permanent meadows and pastures in conversion to organic. In 2013, data collection on Area of arable land and permanent crops under protective cover was introduced. However, the data is not spatially explicit and hence is not easily amenable for GIS analysis.

\subsection{Regional databases}

\section{EUROSTAT}

The Land Use/Cover Area frame Statistical Survey (LUCAS) is a survey carried out by EUROSTAT on the state and the dynamics of changes in land use and cover in the European Union. The surveys are carried out in-situ, with ground observations of land use and landscape made every three years all over the EU. The latest LUCAS survey (2012) covers 27 EU countries and observations on more than 270000 points. From LUCAS survey three types of information are obtained:

- Micro data, i.e. land cover, land use and environmental parameters associated with the surveyed points, such as parcel size and the number and type of landscape elements crossed while walking a 250 metre transect;

- Point and landscape multidirectional pictures in the four cardinal directions;

- Statistical tables with aggregated results by land cover and land use at the geographical level.

LUCAS Land Use is described by a total number of 34 categories and LUCAS Land Cover (LLC) is described by 58 categories. The density of the spatial sampling varies according to different strata, e.g. agricultural land has a higher sampling density than semi-natural or urban areas (Gallego et al., 2011).

\subsection{Country-specific databases}

\section{OECD member countries}

\section{Australia}

The Australian Bureau of Statistics conducts every two years a survey on land accounts regarding land management and farming practices in Australia at national, state and natural resource management region level. Land accounts include land use on farms, land preparation, crop residue management practices, ground cover monitoring, fertiliser use and soil management. ${ }^{21}$

\section{Canada}

Statistics Canada makes available several time series of accounts on land use/cover-related natural resources at different geographic levels, such as land cover by category, area of major sea islands, area of

\footnotetext{
${ }^{21}$ http://www.abs.gov.au/ausstats/abs@.nsf/mf/4627.0
} 
stocked timber-productive forest land burned, forest area harvested, forest fires and forest land burned, forest land, land and freshwater area, mineral reserves, farm irrigation status and irrigated crop area. ${ }^{22}$

Chile

Instituto Nacional de Estadisticas - Chile’s National Statistics Institute - produces every year a report on several environmental themes, including Land and Soils, among others. Under the Land and Soils theme, accounts at the national and regional level are provided regarding the total amount of land and share of each considered land cover and land use type, as well as distinguishing between different types of forest and vegetation, and irrigation technology of agricultural systems. ${ }^{23}$

Japan

The Ministry of Land, Infrastructure, Transport and Tourism (MLIT) and the Ministry of Internal Affairs and Communications (MIC) conduct annual surveys of land cover and land use. ${ }^{24}$

New Zealand

In New Zealand, the Ministry of the Environment provides a number of environmental indicators of land, such as land cover, land use, distribution of native species, area of native land cover and soil erosion risk. $^{25}$

Korea

Surveys on agriculture, forestry and fishery are regularly conducted by Statistics Korea on annual basis, including data series agricultural area, agricultural land lease, crop production and livestock statistics. $^{26}$

\section{United States}

The National Resources Inventory (NRI) - an inventory of the nation's land resources by type of use and cover is conducted by the Natural Resources Conservation Service (NRCS), an agency of the US Department of Agriculture, every 5 years beginning in 1977 through 2003, followed by an assessment in 2007 and 2010. The survey covers all non-federal land for the contiguous 48 states. The following land cover and use-related statistics can be found in the NRI: land and water area, land cover and land use type, wetlands, area of water bodies, soil and wind erosion on cropland, wildfires. ${ }^{27}$

\footnotetext{
${ }^{22}$ http://www5.statcan.gc.ca/subject-sujet/result-resultat?pid=1762\&lang=eng\&id=3786-\&more=0\&type=CST\&pageNum=1

${ }^{23}$ http://www.ine.cl/canales/chile_estadistico/estadisticas_medio_ambiente/medio_ambiente.php

${ }^{24}$ http://www.stat.go.jp/english/data/nenkan/1431-01.htm

${ }^{25}$ http://www.mfe.govt.nz/more/environmental-reporting/land

${ }^{26}$ http://kostat.go.kr/portal/english/surveyOutlines/7/h/index.static

${ }^{27}$ http://www.nrcs.usda.gov/wps/portal/nrcs/main/national/technical/nra/nri/
} 


\section{OECD accession countries}

\section{Costa Rica}

Instituto Nacional de Estadistica y Censos - Costa Rica's National Institute of Statistics and Census - has made available an assessment on forest cover land accounts at the national and regional levels for 2002, 2005 and $2010 .^{28}$

\section{Other G20 countries}

Argentina

Instituto Nacional de Estadistica y Censos - Argentina's National Institute of Statistics and Census - has conducted a detailed survey in 1988, 2002 and 2008 regarding agricultural production at the national, province and department level (Censo Nacional Agropecuario). The survey provides accounts not only on land use, but also crop production, livestock, irrigation, machinery, population and labour. ${ }^{29}$

\section{China (People's Republic of)}

Since 1996, the National Bureau of Statistics of China produces every year a statistical yearbook, including accounts on land use, forest resources, afforestation, forest fires, grassland utilisation and area of wetlands, at the national and the regional levels. ${ }^{30}$

India

India Agristat has a large wealth of time series on land accounts regarding agricultural land use at the national, regional and state level. Some time series are available for relatively long periods, since $1950{ }^{31}$

\section{Saudi Arabia}

Accounts on land in agricultural use are provided by Saudi Arabia's Central Department of Statistics \& Information at the national and regional level regarding land area used for the production of specific crops. ${ }^{32}$

\footnotetext{
${ }^{28}$ http://www.inec.go.cr/Web/Home/GeneradorPagina.aspx

29 http://www.indec.gov.ar/agropecuario/cna_principal.asp

${ }^{30}$ http://www.stats.gov.cn/english/statisticaldata/AnnualData/

${ }^{31}$ http://www.indiaagristat.com/agriculture/2/agriculturalarealanduse/152/stats.aspx

32 http://www.cdsi.gov.sa/english/index.php?option=com docman\&Itemid=169
} 


\section{CONCLUSIONS ON THE USAGE OF THE AVAILABLE DATA}

In the previous chapters, a large number of land cover and land use products were reviewed, with considerable differences found among them in terms of geographic coverage, spatial resolution, temporal resolution, thematic resolution and accuracy. The selection of data sources suitable for computation of land cover and land use-related indicators can be guided by these criteria. A number of guidelines for data selection are given below:

\section{Temporal resolution}

The selected data source should allow for a consistent analysis of changes in land cover and land use patterns for a period long enough to identify trends (assuming that data capture methods, definitions and nomenclatures are consistent over time). Therefore, data sources with reasonably long time series including three or more epochs (e.g. MODIS, CCI-LC, CORINE LC, US NLCD) should be preferred, particularly those produced in regular intervals and for which future updates are expected. Data products that have been produced for a single year (e.g. GLCC, GLC2000, FROM-GLC $30 \mathrm{~m}$ ) have fewer potential uses.

\section{Geographic coverage and spatial resolution}

Country-specific datasets are produced by local experts and can be expected to be more accurate and have a thematic resolution better able to capture the specific local patterns. Moreover, datasets with high spatial resolution should be preferred in order to allow capturing finer-scale land cover and land use change processes, such as urban sprawl and landscape fragmentation, and more generally because higher spatial resolution allows improving the accuracy and reliability of the data. However, global and regional datasets offering a relatively fine spatial resolution can also be considered as a good option for some uses because they allow achieving a better comparability across countries and as single datasets they can be more easily handled (e.g. GlobCover at 300m, CCI-LC at 300m, and CORINE LC at 100m resolution).

\section{Thematic resolution}

The available data sources vary widely in terms of the thematic resolution and the classification system used. As a first guideline, data products with standardised, unambiguous classification systems should be given preference, in order to allow for inter-comparability or cross-walking between legends with different resolution.

Second, datasets with more refined thematic resolutions should be given priority, particularly if the legends allow distinguishing between regionally-specific types of vegetation cover and sector-specific types of land use. These legends should, however, be flexible enough to be aggregated in more general classes, in order to also allow assessing more general land cover and land use change processes. For example, the FAO-LCCS hierarchical system offers more consistency owing to its ability to accommodate different levels of information, starting with structured broad-level classes which allow further systematic subdivision into more detailed sub-classes.

\section{Summary}

Taking into account the criteria discussed above, we conducted an assessment of the reviewed datasets regarding their suitability to compute internationally comparable land cover and land use indicators across a large number of OECD and G20 countries. The following datasets are potentially useful data sources; however it is not clear that any currently available data sources can be used to produce reasonably harmonised and methodologically robust information about changes in land cover and land use across all OECD and G20 countries: 
- CCI-LC's goal is to provide a consistent series of land cover data at a reasonable spatial and thematic resolution for a global dataset, with a legend based on the FAO-LCCS system. It is thus a potentially suitable data source to be used for the computation of land cover indicators for all OECD and G20 countries. In its current iteration, only changes to and from forested land cover types are modelled in the 2000-2005-2010 time series, however further developments may be released in the future.

- CORINE LC provides a reliable and consistent time series of land cover and land use maps, covering a large number of European countries with detailed spatial and thematic resolution, using a hierarchical classification system based on the FAO-LCCS system. Therefore, this is also a likely candidate to be used for the computation of land cover and land use indicators in the following countries: EU-28, EFTA, Balkan countries and Turkey.

- Australia's National Dynamic Land Cover has a reasonable spatial resolution and detailed thematic resolution of land cover. Therefore, it could eventually become a suitable data source for the computation of land cover indicators in Australia, but only provided that the expected time series between 2000 and 2010 become available.

- $\quad$ ALUMP provide a relatively long and consistent data series of land use and therefore could be considered a suitable data source for the computation of land use indicators in Australia. However, it should be noted that its scale is rather coarse, which might have some implications for its suitability for the computation of indicators measuring patterns that typically are better captured with a fine resolution, such as urban development.

- Catastro de los Recursos Vegetacionales Nativos de Chile provides a consistent time series of land cover and land use data with a very detailed scale, although it should be noted that the thematic resolution of land use is more detailed for forest resources only. The accuracy of the datasets is unknown however it was deemed credible by the FAO which has used it for the assessment of forest resources in Chile (FAO, 2010). Therefore, this can be considered a suitable data source for the computation of land cover and forest land use indicators in Chile, provided that access to all datasets is provided (only the 2011 dataset was available for download).

- National Land Numerical Information provides a relatively long time series of land use data with a detailed scale and furthermore it could be considered as a suitable option for the computation of both land cover and land use indicators in Japan. However, it should be noted that its classification is not fully consistent, and therefore some reclassification adjustments might be needed. Furthermore, the mesh format of the dataset does not allow the computation of transition matrices.

- Uso del Suelo y Vegetacion has a reasonable spatial resolution and detailed thematic resolution of land cover. Therefore, it could eventually become a suitable data source for the computation of land cover indicators in Mexico, but only provided that access to all datasets is provided (only the 2011 dataset was available for download).

- $\quad$ LUCAS LUM seems to provide a fairly good option for the computation of land cover indicators in New Zealand. It should be noted that information about its spatial scale could not be retrieved. However, after visual inspection it could be concluded that the dataset seems to offer enough spatial detail.

- US NLCD provides a reliable and consistent data series of land cover with a very detailed spatial resolution, and a legend distinguishing between different intensities of urban land use that can be cross-walked to other legend systems. Thus, this is a suitable option for the computation of land cover indicators and, to a lesser extent, land use indicators in the United States. 
- Alternatively, data from the North American Land Change Monitoring System (NALCMS) project may be used to describe land cover in Canada, Mexico and the United States. The dataset has a fairly fine resolution (250 m) and is available for two time steps (2005 and 2010).

2. Several conclusions can be drawn from the presented review of data availability. First, land cover data seems to be widely available, although not all countries have consistent data series available and the quality varies among data sources. For the computation of land cover indicators two alternatives are possible:

- $\quad$ Use the best-available land cover data source for each specific country (group of countries): This is likely to maximise accuracy for each country/region. The adoption of a common land cover and land use classification framework might be required in order to harmonise the different data sources and ensure a certain degree of inter-comparability. For instance, the SEEA framework (Annex A.3; SEEA, 2014) offers a good option for general land cover standard classification. The SEEA classification is conceptually based on the FAO-LCCS and provides a clear and systematic description of land cover classes. Adoption of such a standard can facilitate the compilation of data and improve the comparability of indicators among the OECD and other international organisations (e.g. UN, European Union, and the World Bank). However, even with a standard classification framework, differences in periodicity, input sensor data, resolution and classification technique would limit harmonisation and comparability between different data sources.

- Use the same data source for all countries, for example the CCI-LC global data series: This alternative trades off higher accuracy for improved inter-comparability among geographic units.

3. Second, land use data sources seem to be scarcer, available only for Australia, Europe, Japan and the United States. Two alternatives are possible regarding the computation of land use indicators:

- $\quad$ Since a single land use data source covering all OECD and G20 countries is not available, land use indicators can be computed only for those countries where land use data are available, using the best-available data sources.

- Generate datasets with a more refined thematic land use classification by combining land cover data with ancillary data sources. For example, online-distributed geospatial services (e.g. OpenStreetMap) and navigation data (e.g. TeleAtlas) can provide additional sources of information to distinguish different land uses within artificial surface areas. (As an example, see Batista e Silva et al. 2013 for an approach to apply ancillary data to obtain a more refined land cover and land use map.) 


\section{REFERENCES}

Batista e Silva, F., C. Lavalle and E. Koomen (2013), A procedure to obtain a refined European land use/cover map. Journal of Land Use Science, 8 (3), pp. 255-283.

Bicheron, P., P. Defourny, C. Brockmann, L. Schouten, C. Vancutsem, M. Huc, S. Bontemps, M. Leroy, F. Achard, M. Herold, F. Ranera and O. Arino (2008), Globcover: Products Description and Validation Report. Medias-France, Université Catholique de Louvain, Brockman Consult, Infram, EC-JRC, GOFC-GOLD, European Space Agency.

Bontemps, S., P. Defourny, E. Van Bogaert, O. Arino, V. Kalogirou and J. R. Perez (2011), Globcover: Products Description and Validation Report. Université Catholique de Louvain, European Space Agency.

Chen, J., J. Chen, A. Liao, X. Cao, L. Chen, X. Chen, C. He, G. Han, S. Peng, M. Lu, W. Zhang, X. Tong and J. Mills (2014), Global land cover mapping at $30 \mathrm{~m}$ resolution: A POK-based operational approach. ISPRS Journal of Photogrammetry and Remote Sensing, in press.

Cihlar, J. and J. Beaubien, (1998), Land cover of Canada Version 1.1. Special Publication, NBIOME Project. Produced by the Canada Centre for Remote Sensing and the Canadian Forest Service, Natural Resources Canada.

Comber, A.J. (2008), Land use or land cover? Journal of Land Use Science 3 (4), pp. 199-202.

De Fries, R. S., M. Hansen, J. R. G. Townshend and R. Sohlberg (1998), Global land cover classifications at $8 \mathrm{~km}$ spatial resolution: the use of training data derived from Landsat imagery in decision tree classifiers. International Journal of Remote Sensing 19 (16), pp. 3141-3168.

Di Gregorio, A. and L.J.M. Jansen (2000), Land Cover Classification System: Classification Concepts and User Manual. FAO, Rome.

EEA (2006), The thematic accuracy of CORINE Land Cover 2000: Assessment Using LUCAS (Land Use/Cover Area Frame Statistical Survey). Technical Report 7/2006, European Environment Agency.

FAO (2010), Evaluación de los recursos forestales mundiales 2010 - Informe Nacional Chile. Forest Department, Food and Agriculture Organization of the United Nations, Rome, Italy.

Friedl, M.A. et al. (2002), Global land cover mapping from MODIS: algorithms and early results. Remote Sensing of Environment 83, pp. 287-302.

Friedl, M.A, D. Sulla-Menashe, B. Tan, A. Schneider, N. Ramankutty, A. Sibley and X. Huang (2010), MODIS Collection 5 global land cover: Algorithm refinements and characterization of new datasets. Remote Sensing of Environment 114 (1), pp. 168-182.

Fritz, S., et al. (2003), Harmonisation, mosaicing and production of the Global Land Cover 2000 database. Report nr. EUR 20849 EN, Joint Research Centre Directorate-General, European Commission.

Gallego, F.J., F. Batista, C. Rocha and S. Mubareka (2011), Disaggregating population density of the European Union with CORINE land cover. International Journal of Geographical Information Science 25 (12), pp. 2051-2069. 
Giri, C. and Z. Zhu (2003), GLC-2000 North America: Classification and Results Validation. Presentation at the GLC 2000 Final Results Workshop, Joint Research Center, Ispra, Italy, pp. 24-26 March 2003.

Gong, P., et al. (2013), Finer resolution observation and monitoring of global land cover: first mapping results with Landsat TM and ETM+ data. International Journal of Remote Sensing 34 (7), pp. 26072654.

Gutman, G., R. Byrnes, J. Masek, S. Covington, C. Justice, S. Franks and R. Headley (2008), Towards monitoring land-cover and land-use changes at a global scale: The Global Land Survey 2005. Photogrammetric Engineering \& Remote Sensing 74, pp. 6-10.

Haines-Young (2009), Land use and biodiversity relationships. Land Use Policy 26S: S178-S186.

Hansen, M. C., R. S. De Fries, J. R. G. Townshend and R. Sohlberg (2000), Global land cover classification at $1 \mathrm{~km}$ spatial resolution using a classification tree approach. International Journal of Remote Sensing 21 (6): pp. 1331-1364.

Hansen, M. C., P. V. Potapov, R. Moore, M. Hancher, S. A. Turubanova, A. Tyukavina, D. Thau, S. V. Stehman, S. J. Goetz, T. R. Loveland, A. Kommareddy, A. Egorov, L. Chini, C. O. Justice, and J. R. G. Townshend. 2013. High-Resolution Global Maps of 21st-Century Forest Cover Change. Science 342 (15 November): 850-53. Data available on-line from: http://earthenginepartners.appspot.com/science-2013global-forest.

INTA (2009), Monitoreo de la Cobertura y el Uso del Suelo a partir de sensores remotos. Project report PNECO1643 Programa Nacional de Ecorregiones. Instituto Nacional de Tecnologia Agropecuaria, Argentina.

http://inta.gob.ar/documentos/cobertura-del-suelo-de-la-republica-argentina.-ano-2006-2007-lccsfao/at_multi_download/file/INFORME\%20TECNICO\%20lccs.pdf.

Jun, C., Y. Ban and S. Li (2014), China: Open access to Earth land-cover map. Nature 514: 434.

Jung, M., K. Henkel, M. Herold and G. Churkina (2006), Exploiting synergies of global land cover products for carbon cycle modeling. Remote Sensing of Environment 101, pp. 534-553.

Kirches, G., C. Brockmann, M. Boettcher, M. Peters, S. Bontemps, C. Lamarche, M. Schlerf, M. Santoro and P. Defourny (2014), CCI-LC Product User Guide. Université Catholique de Louvain, Brockmann Consult, University of Jena, the Joint Research Center and Wageningen University.

Latham, J., R. Cumani, I. Rosati and M. Bloise (2014), Global Land Cover SHARE (GLC-SHARE) database: Beta-Release Version 1.0 - 2014. FAO, Rome, Italy.

NRC (2014), Land Cover, circa 2000 - Vector. Natural Resources Canada, Earth and Sciences Sector, Canada Centre for Mapping and Earth Observation.

NZME (2012), LUCAS Land Use Map Data Description. New Zealand Ministry for the Environment.

NZME (2014), Accuracy Assessment of LUCAS 2012 Land Use Map. Final Report. New Zealand Ministry for the Environment.

RDLR (2009), Development of a methodology for national land use mapping for chief directorate: geospatial information. Department of Rural Development \& Land Reform, Republic of South Africa. http://www.ngi.gov.za/index.php/technical-information/publications-research-reports/national-land-use-and-cover.

Schneider, A., M. Friedl and D. Potere (2009), A new map of global urban extent from MODIS data. Environmental Research Letters, Vol. 4, article 044003. 
SEEA (2014), System of Environmental-Economic Accounting 2012 Central Framework. United Nations, European Union, Food and Agriculture Organization of the United Nations, International Monetary Fund, Organisation for Economic Co-operation and Development, World Bank.

Srebro, H., Y. Felus and Y. Tal (2010), New initiatives in ISDI (Israeli NSDI). ISPRS Archive Vol. XXXVIII, Part 4-8-2-W9, "Core Spatial Databases - Updating, Maintenance and Services - from Theory to Practice”. Haifa, Israel.

Stolbovoi, V., G. Fischer, V. Sizov and B. Rozhkova (1997), The IIASA-LUC project Georeferenced Database of the Former U.S.S.R., Vol. 5: Land categories. IR-97-087/December, IIASA, Laxenburg, Austria.

Wickham, J.D., S.V. Stehman, L. Gass, J. Dewitz, J.A. Fry and T.G. Wade (2013), Accuracy assessment of NLCD 2006 land cover and impervious surface. Remote Sensing of Environment 130, pp. 294-304.

Yu, L., J. Wang, J. and P. Gong, (2013a), Improving 30 meter global land cover map FROM-GLC with time series MODIS and auxiliary datasets: a segmentation based approach. International Journal of Remote Sensing 34 (16), pp. 5851-5867.

Yu, L., Wang, J., N. Clinton, Q.C. Xin, L.H. Zhong, Y.L. Chen and P. Gong (2013b), FROM-GC: 30 m global cropland extent derived through multisource data integration. International Journal of Digital Earth 6 (6),pp. 521-533.

Yu, L. et al. (2014a), Meta-discoveries from a synthesis of satellite-based land cover mapping research. International Journal of Remote Sensing 35 (13), pp. 4573-4588.

Yu, L., J. Wang, X.C. Li, C.C. Li and P. Gong, P. (2014b), A multi-resolution global land cover dataset through multisource data aggregation. Science China Earth Sciences 57 (10), pp. 2317-2329.

Zhao,Y., Gong, P., Yu, L., Hu, L., Li, X., Li, C., Zhang, H., Zheng, Y., Wang, J., Zhao, Y., Cheng, Q., Liu, C., Liu, S., Wang, X. (2014), Towards a common validation sample set for global land-cover mapping. International Journal of Remote Sensing 35 (13): 4795-4814. 


\section{ANNEX A: SYSTEMS OF LAND COVER AND LAND USE CLASSIFICATION}

\section{A.1. IGBP classification}

The International Global Biosphere Programme (IGBP) global land cover classification was made to support a number of IGBP initiatives. The legend was chosen to be exhaustive, so that every part of the Earth's surface can be assigned to a class; exclusive, so that classes did not overlap; and structured so that classes are equally interpretable with higher resolution remotely-sensed imagery, or ground observation. The categories were chosen so that they embraced the climate-independence and canopy component, as well as being compatible with other classification schemes to provide, where possible, land use implications and to represent landscape mosaics. The legend comprises 17 so-called DISCover classes as defined below.

\begin{tabular}{|c|c|c|}
\hline CLASS & CLASS NAME & DESCRIPTION \\
\hline 1 & $\begin{array}{l}\text { Evergreen } \\
\text { Needleleaf Forests }\end{array}$ & $\begin{array}{l}\text { Lands dominated by trees with a percent canopy cover }>60 \% \text { and height } \\
\text { exceeding } 2 \text { meters. Almost all trees remain green all year. Canopy is } \\
\text { never without green foliage. }\end{array}$ \\
\hline 2 & $\begin{array}{l}\text { Evergreen } \\
\text { Broadleaf Forests }\end{array}$ & $\begin{array}{l}\text { Lands dominated by trees with a percent canopy cover }>60 \% \text { and height } \\
\text { exceeding } 2 \text { meters. Almost all trees remain green all year. Canopy is } \\
\text { never without green foliage. }\end{array}$ \\
\hline 3 & $\begin{array}{l}\text { Deciduous } \\
\text { Needleleaf Forests }\end{array}$ & $\begin{array}{l}\text { Lands dominated by trees with a percent canopy cover }>60 \% \text { and height } \\
\text { exceeding } 2 \text { meters. Consists of seasonal needleleaf tree communities with } \\
\text { an annual cycle of leaf-on and leaf-off periods. }\end{array}$ \\
\hline 4 & $\begin{array}{l}\text { Deciduous } \\
\text { Broadleaf Forests }\end{array}$ & $\begin{array}{l}\text { Lands dominated by trees with a percent canopy cover }>60 \% \text { and height } \\
\text { exceeding } 2 \text { meters. Consists of seasonal broadleaf tree communities with } \\
\text { an annual cycle of leaf-on and leaf-off periods. }\end{array}$ \\
\hline 5 & Mixed Forests & $\begin{array}{l}\text { Lands dominated by trees with a percent canopy cover }>60 \% \text { and height } \\
\text { exceeding } 2 \text { meters. Consists of tree communities with interspersed } \\
\text { mixtures or mosaics of the other four forest cover types. None of the forest } \\
\text { types exceeds } 60 \% \text { of landscape. }\end{array}$ \\
\hline 6 & Closed Shrublands & $\begin{array}{l}\text { Lands with woody vegetation less than } 2 \text { meters tall and with shrub } \\
\text { canopy cover is }>60 \% \text {. The shrub foliage can be either evergreen or } \\
\text { deciduous. }\end{array}$ \\
\hline 7 & Open Shrublands & $\begin{array}{l}\text { Lands with woody vegetation less than } 2 \text { meters tall and with shrub } \\
\text { canopy cover is between } 10-60 \% \text {. The shrub foliage can be either } \\
\text { evergreen or deciduous. }\end{array}$ \\
\hline 8 & Woody Savannas & $\begin{array}{l}\text { Lands with herbaceous and other understorey systems, and with forest } \\
\text { canopy cover between } 30-60 \% \text {. The forest cover height exceeds } 2 \text { meters. }\end{array}$ \\
\hline 9 & Savannas & $\begin{array}{l}\text { Lands with herbaceous and other understorey systems, and with forest } \\
\text { canopy cover between } 10-30 \% \text {. The forest cover height exceeds } 2 \text { meters. }\end{array}$ \\
\hline 10 & Grasslands & $\begin{array}{l}\text { Lands with herbaceous types of cover. Tree and shrub cover is less than } \\
10 \% \text {. }\end{array}$ \\
\hline 11 & $\begin{array}{l}\text { Permanent } \\
\text { Wetlands }\end{array}$ & $\begin{array}{l}\text { Lands with a permanent mixture of water and herbaceous or woody } \\
\text { vegetation that cover extensive areas. The vegetation can be present in } \\
\text { either salt, brackish, or fresh water. }\end{array}$ \\
\hline 12 & Cropland & $\begin{array}{l}\text { Lands covered with temporary crops followed by harvest and a bare soil } \\
\text { period (e.g., single and multiple cropping systems. Note that perennial } \\
\text { woody crops will be classified as the appropriate forest or shrub land } \\
\text { cover type. }\end{array}$ \\
\hline 13 & Urban and Built-up & $\begin{array}{l}\text { Land covered by buildings and other man-made structures. Note that this } \\
\text { class will not be mapped from the AVHRR imagery but will be developed } \\
\text { from the populated places layer that is part of the Digital Chart of the } \\
\text { World. }\end{array}$ \\
\hline 14 & $\begin{array}{l}\text { Cropland/Natural } \\
\text { Vegetation Mosaics }\end{array}$ & $\begin{array}{l}\text { Lands with a mosaic of croplands, forest, shrublands, and grasslands in } \\
\text { which no one component comprises more than } 60 \% \text { of the landscape. }\end{array}$ \\
\hline 15 & Snow and Ice & Lands under snow and/or ice cover throughout the year. \\
\hline 16 & Barren & $\begin{array}{l}\text { Lands exposed soil, sand, rocks, or snow and never has more than } 10 \% \\
\text { vegetated cover during any time of the year. }\end{array}$ \\
\hline 17 & Water Bodies & $\begin{array}{l}\text { Oceans, seas, lakes, reservoirs, and rivers. Can be either fresh or salt water } \\
\text { bodies }\end{array}$ \\
\hline
\end{tabular}




\section{A.2. FAO-LCCS classification}

The FAO-Land Cover Classification System (FAO-LCCS) is a comprehensive, standardised a priori classification system, designed to meet specific user requirements, and created for mapping exercises, independent of the scale or means used to map. The classification uses a set of independent diagnostic criteria that allow correlation with existing classifications and legends. Land cover classes are defined by a combination of a set of independent diagnostic criteria - the so-called classifiers - that are hierarchically arranged to assure a high degree of geographical accuracy. Because of the heterogeneity of land cover, the same set of classifiers cannot be used to define all land cover types. The hierarchical structure of the classifiers may differ from one land cover type to another. Therefore, the classification has two main phases:

- $\quad$ an initial Dichotomous Phase, where eight major land cover types are distinguished; and

- a subsequent Modular-Hierarchical Phase where the set of classifiers and their hierarchical arrangement are tailored to the major land cover type.

This approach allows the use of the most appropriate classifiers and reduces the total number of impractical combinations of classifiers. The classification system leads to mutually exclusive land cover classes, which comprise: (1) a unique Boolean formula (a coded string of classifiers used); (2) a standard name; and (3) a unique numerical code. Both the numerical code and standard name can be used to build an automatically generated Legend, with the classes created grouped according to the main land cover categories and their domains according to the level of detail. The nomenclature can be linked to a userdefined name in any language.

Further definition of the Land Cover Class can be achieved by adding attributes. Two types of attributes, which form separate levels in the classification, are distinguished:

- Environmental Attributes: these are attributes (e.g., climate, landform, altitude, soil, lithology and erosion) which influence land cover but are not inherent features of it and should not be mixed with "pure" land cover classifiers;

- $\quad$ Specific Technical Attributes: these are associated with specific technical disciplines (e.g. for (Semi-)Natural Vegetation, the Floristic Aspect can be added; for Cultivated Areas, the Crop Type; and for Bare Soil, the Soil Type).

All Primarily Vegetated land cover classes are derived from a consistent physiognomic-structural conceptual approach that combines the classifiers Life Form, Cover and Height (in [Semi] Natural Vegetation) and Life Form (in Cultivated Areas) with Spatial Distribution. The Primarily Non-Vegetated classes have a similar approach, using classifiers that deal with surface aspects, distribution/density and height/depth.

The advantages of the classifier, or parametric, approach are manifold. The system created is a highly flexible a priori land cover classification in which each land cover class is clearly and systematically defined, thus providing internal consistency. The system is truly hierarchical and applicable at a variety of scales. Re-arrangement of the classes based on re-grouping of the classifiers used facilitates extensive use of the outputs by a wide variety of end-users. Accuracy assessment of the end product can be generated by class or by the individual classifiers forming the class. All land covers can be accommodated in this highly flexible system; the classification could therefore serve as a universally applicable reference base for land cover, thus contributing towards data harmonisation and standardisation. 


\section{A.3. SEEA classification}

There are an enormous number of different land cover features that can be created with the LCCS approach. For the purposes of standardisation and harmonisation across statistical data sets, a classification comprising 14 classes has been established. The 14 classes constitute a comprehensive set of land cover types with clear boundaries based on definitions from the LCCS that are mutually exclusive and unambiguous. This land cover classification can be used at all scales, independently of the method of observation, thus allowing cross-referencing of local and regional maps with continental and global maps without loss of information. The land cover classification is complemented with a set of basic rules of classification to allow translation of national data sets. The rules reflect the logical structure of the LCCS and determine, as the first step, the main object (the "basic object") to be considered when undertaking a translation of data. The basic objects are simple and intuitively discernible elements of land cover (such as trees, shrubs, buildings, etc.). The descriptions are supplemented by the inclusion of information on "properties" (such as height, cover, etc.) and "characteristics" (natural, cultivated, etc.) of the basic objects.

\section{Land cover classification}

1 Artificial surfaces (including urban and associated areas)

2 Herbaceous crops

3 Woody crops

4 Multiple or layered crops

5 Grassland

6 Tree-covered areas

7 Mangroves

8 Shrub-covered areas

9 Shrubs and/or herbaceous vegetation, aquatic or regularly flooded

10 Sparsely natural vegetated areas

11 Terrestrial barren land

12 Permanent snow and glaciers

13 Inland water bodies

14 Coastal water bodies and intertidal areas

Land use reflects both the activities undertaken and the institutional arrangements put in place for a given area for the purposes of economic production, or the maintenance and restoration of environmental functions. In effect, "use" of an area implies the existence of some human intervention or management. Land in use therefore includes areas, for example, protected areas, that are under the active management of institutional units of a country for the purpose of excluding economic or human activity from that area. Not all land in a country is used following the definition above. Some areas are "not in use", although they may have a use in supporting ecosystems and biodiversity. In order to provide a complete accounting for land use within a country, both land in use and land not in use must be included.

The scope of land use accounts comprises areas of land and inland water. For some analytical purposes, and depending on the composition of a country's economic territory, the measurement boundary for land use may be extended to include coastal waters and areas within a country. Such a broader boundary is likely to be of relevance in the management of fishing rights, offshore mining and exploration, the protection of coral reefs, and the understanding of other marine issues. Particularly in cases where the area of a country's coastal water and EEZ constitutes a large part of its economic territory, this extension of the analysis of land use is appropriate. 


\section{Land use classification}

1 Land

1.1 Agriculture

1.2 Forestry

1.3 Land used for aquaculture

1.4 Use of built-up and related areas

1.5 Land used for maintenance and restoration of environmental functions

1.6 Other uses of land not elsewhere classified

1.7 Land not in use

2 Inland waters

2.1 Inland waters used for aquaculture or holding facilities

2.2 Inland waters used for maintenance and restoration of environmental functions

2.3 Other uses of inland waters not elsewhere classified

2.4 Inland waters not in use

\section{A.4. CORINE classification}

\section{Corine land cover classes}

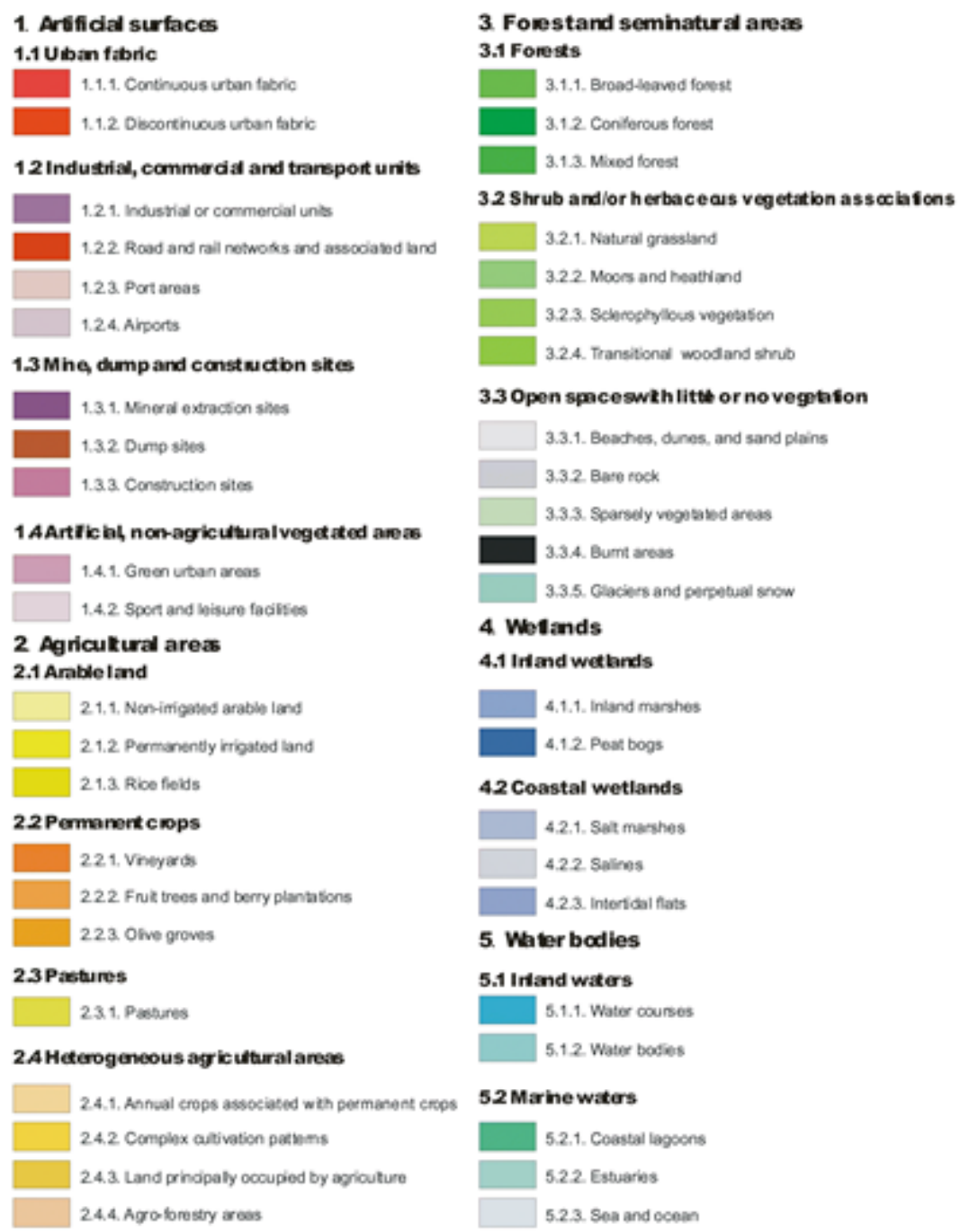




\section{A.5. Anderson Land Cover Classification System}

The Anderson Land Cover Classification System has been developed to meet the needs of Federal and State agencies of the United States for an overview of land use and land cover throughout the country on a basis that is uniform in categorisation at the more generalised first and second levels and that will be receptive to data from satellite and aircraft remote sensors. The proposed system uses the features of existing widely used classification systems that are amenable to data derived from remote sensing sources.

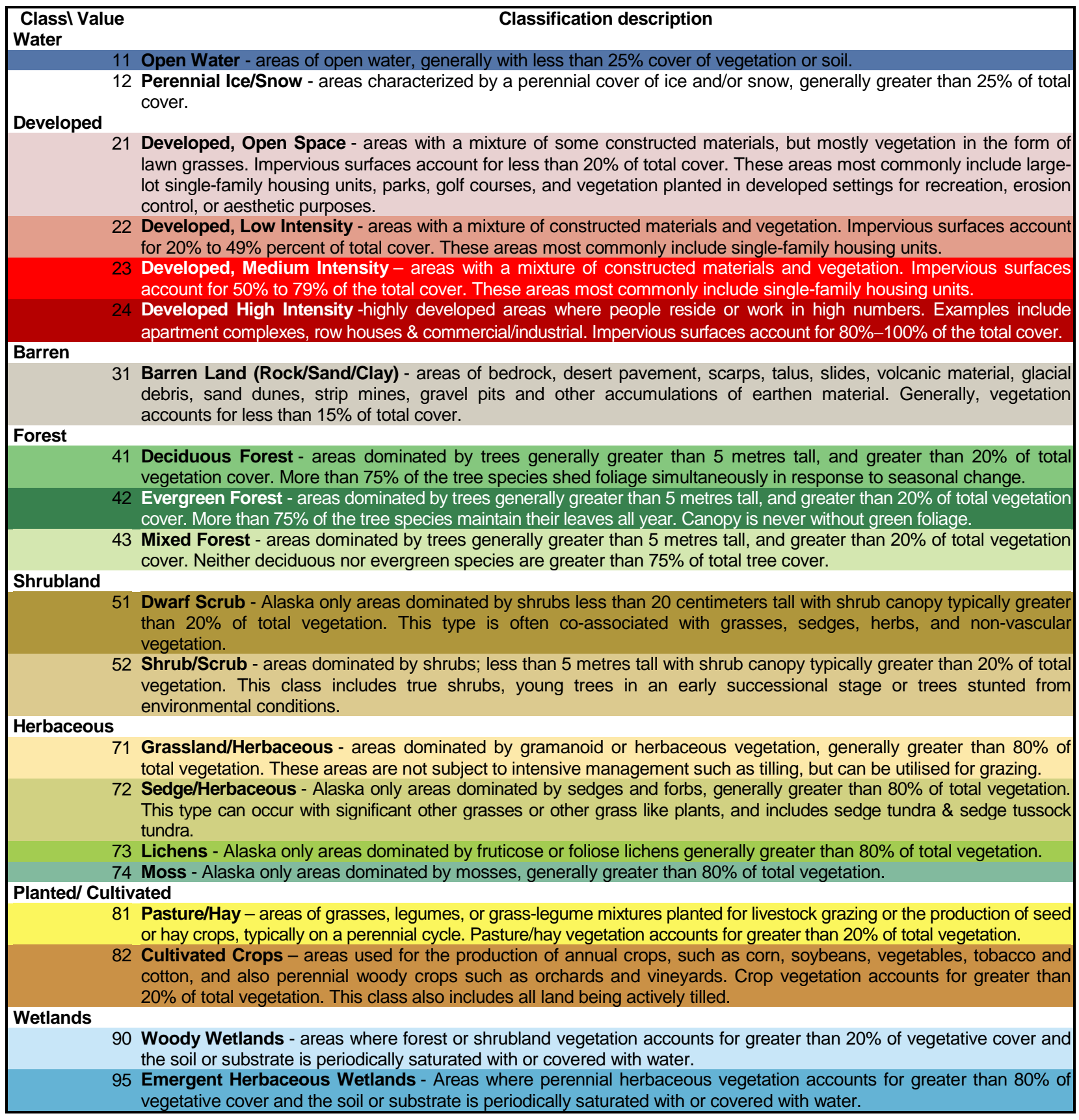




\section{ANNEX B: SELECTED SOURCES OF ENVIRONMENTAL, GEOPHYSICAL AND SOCIO-ECONOMIC GEO-REFERENCED DATA}

- Conservation status of habitat types and species (Article 17, Habitats Directive 92/43/EEC) http://www.eea.europa.eu/data-and-maps/data/article-17-database-habitats-directive-92-43-eec

- Copernicus: European Earth Observation Centre http://www.copernicus.eu/

- JRC European Forest Data Centre http://forest.jrc.ec.europa.eu/efdac/

- Commission for environmental cooperation: North American Environmental Atlas http://www.cec.org/Page.asp?PageID=122\&ContentID=2336

- USGS list of datasets http://landcover.usgs.gov/landcoverdata.php

- Global Land Cover Facility http://www.landcover.org/

- European Environment Agency http://www.eea.europa.eu/data-and-maps

- European Space Agency (ESA) http://due.esrin.esa.int/projects.php

- IIASA GAEZ crop suitability, (agricultural) land resources http://www.gaez.iiasa.ac.at/

- World Database of Protected Areas http://www.iucn.org/about/work/programmes/gpap_home/gpap_biodiversity/gpap_wdpa/

- FAO Geonetwork http://www.fao.org/geonetwork/srv/en/main.home

- UNEP-GRID Environmental Data explorer http://geodata.grid.unep.ch/

- SEDAC Portal to Environmental and Socioeconomic Data http://sedac.ciesin.columbia.edu/wdc/

- LANDScan global population distribution data http://web.ornl.gov/sci/landscan/

- US Geological Survey (USGS) Earth Resources Observation and Science (EROS) http://eros.usgs.gov/find-data

- IUCN Red List of Threatened species spatial data http://www.iucnredlist.org/technicaldocuments/spatial-data

- WorldClim: Past, Current and Future Global Climate Data http://www.worldclim.org/download

- UNdata http://data.un.org/

- JRC Land Resource Management Unit http://bioval.jrc.ec.europa.eu/

- Global Accessibility Map http://bioval.jrc.ec.europa.eu/products/gam/index.htm

- World Bank database http://data.worldbank.org/

- Air Pollution in World Cities (PM10 Concentrations) http://econ.worldbank.org/WBSITE/EXTERNAL/EXTDEC/EXTRESEARCH/0,,contentMDK:20 785646 pagePK:64214825 piPK:64214943 theSitePK:469382,00.html

- GRIP: Global Roads Inventory Project http://geoservice.pbl.nl/geonetwork/srv/nl/main.home\# 
www.oecd.org/greengrowth 